Oak Ridge National Laboratory

\title{
Annual Sustainability Report
}

4y $x=x$

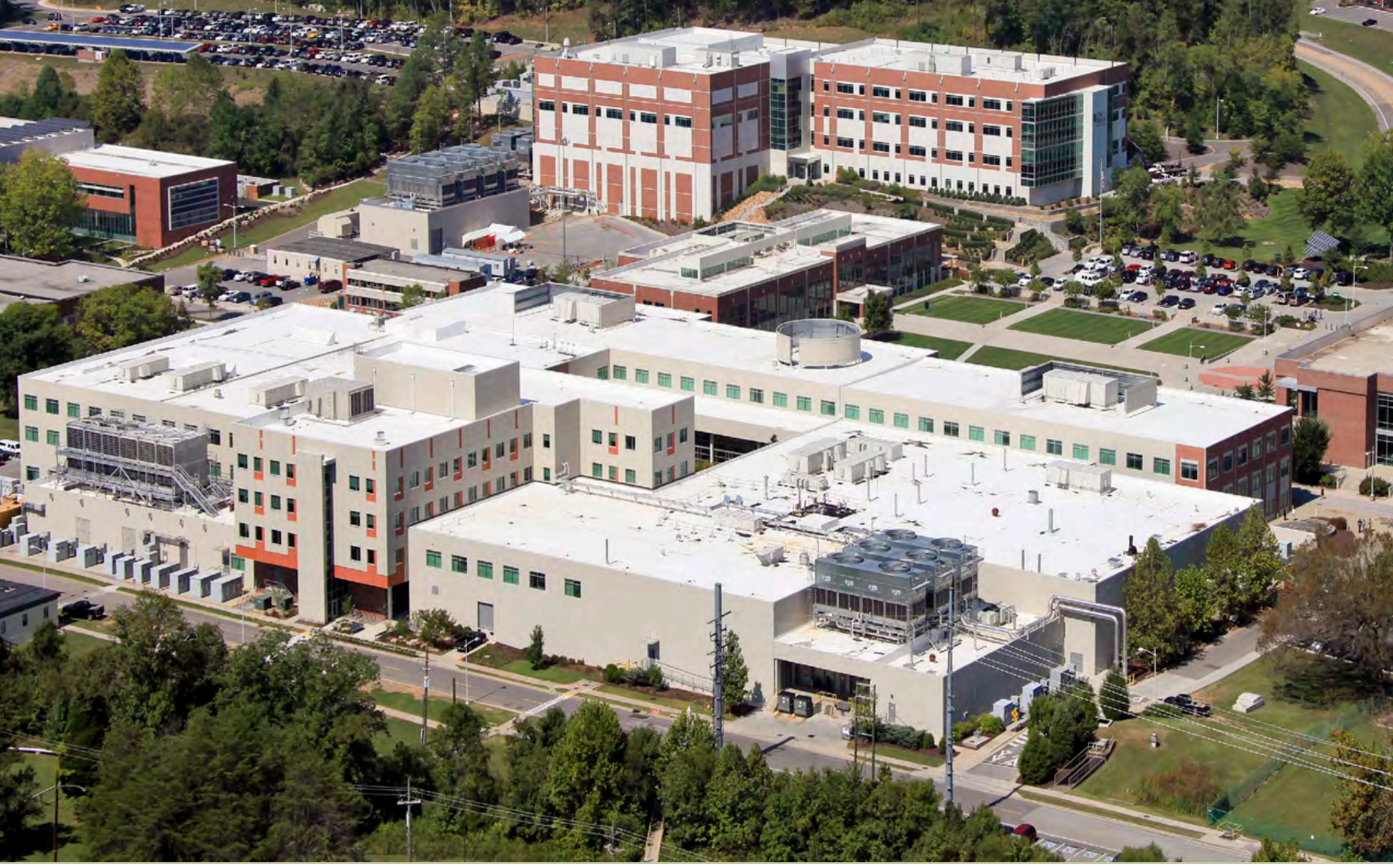

(D) ENERGY

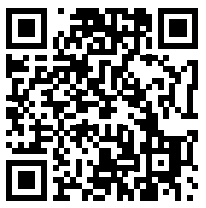




\section{Contents}

Message from the Director $\quad 1$

Introduction 2

ORNL Overview 2

Sustainable Campus Initiative $\quad 2$

This Report 3

Energy Efficiency and Renewables 4

Energy Intensity Reduction 4

Green Computing 4

Utilities $\quad 6$

Automated Monitoring for Energy Efficiency $\quad 8$

Renewable Energy $\quad 8$

$\begin{array}{lr}\text { ORNL Leads in LEED Certification } & 10\end{array}$

Transportation $\quad 12$

Fleet Management 12

Employee Commuting 13

$\begin{array}{ll}\text { Regional Transportation Coordination } & 15\end{array}$

Pollution Prevention $\quad 16$

Municipal, Construction, and Demolition Waste 17

$\begin{array}{ll}\text { Continuing Efforts } & 17\end{array}$

$\begin{array}{ll}\text { Greenhouse Gas Management } & 18\end{array}$

Safety, Health, and Wellness 20

Environmental and Safety Performance $\quad 20$

$\begin{array}{ll}\text { Wellness Program } & 20\end{array}$

Community Engagement $\quad 22$

Southeast Sustainability Summit $\quad 22$

ORNL Charter Member of New Sustainability Group $\quad 22$

Community Sustainability Award 22

Global Reporting Initiative and the Sustainable Campus Initiative 24 


\section{Message from the Director}

Our mission at Oak Ridge National Laboratory (ORNL), the largest science and energy laboratory in the US Department of Energy (DOE) system, is to deliver scientific discoveries and technical breakthroughs that will accelerate the development and deployment of solutions in clean energy and global security and, in doing so, create economic opportunity for the nation. Much of the research and development (R\&D) conducted at ORNL is focused on DOE's goal of transforming the nation's energy system and securing US leadership in clean energy technologies.

By combining the outcomes of this R\&D with a commitment to sustainability in all of our activities, we are making progress in transforming the laboratory's physical environment and meeting DOE goals for energy management and environmental performance. Our Sustainable Campus Initiative, a 10-year effort to achieve benchmark levels of sustainability across ORNL, provides the framework for our efforts to

- increase the energy efficiency and reduce the environmental impact of our facilities and operations;

- lower our greenhouse gas emissions;

- conserve and protect water resources;

- eliminate waste, increase recycling, and prevent pollution;

- design, construct, maintain, and operate high performance sustainable buildings in sustainable locations;

- strengthen the vitality and livability of the community around us; and

- engage our employees in the achievement of these goals.

As described in this report, we have made substantial progress across the 25 roadmaps of the Sustainable Campus Initiative. The report also outlines our plans to continue integrating sustainable practices into the planning, execution, and evaluation of all ORNL activities. We appreciate your interest in our journey to sustainability, and we welcome your comments, questions, and suggestions. 


\section{Introduction}

\section{ORNL at a Glance}

- Established 1943 as part of the World War II Manhattan Project

- Managed for DOE by UT-Battelle, a partnership between the University of Tennessee and Battelle Memorial Institute

- More than 5 million $\mathrm{ft}^{2}$ of buildings on 4,400 acres of land

- Staff: $>4,400$

- Research staff: 1,600 scientists and engineers

- Guest researchers: 3,000 annually

- Budget: $\$ 1.65$ billion

- R\&D 100 awards: 179

\section{ORNL Overview}

Oak Ridge National Laboratory (ORNL) is the largest science and energy national laboratory in the US Department of Energy (DOE) system. ORNL's scientific programs focus on materials, neutron science, energy, high performance computing, systems biology, and national security. ORNL partners with the State of Tennessee, universities, and industry to solve challenges in energy, advanced materials, manufacturing, security, and physics. The laboratory's science and technology innovations are translated into applications for economic development and global security.

It's difficult to find an area of campus that hasn't been touched by the SCl team. Sustainable lighting, energy efficiency, water conservation, sustainable landscaping, electric vehicle charging stations - the list goes on and on. What impresses me most is that the team has been instrumental in changing behaviors at the campus. Sustainability is no longer an afterthought but a first consideration in nearly everything we do.

- Herb Debban, Director of Programs, Facilities and Operations Directorate, and Cosponsor of ORNL's Sustainable Campus Initiative

ORNL is home to several of the world's top supercomputers and is a leading neutron science and nuclear energy research facility that includes the Spallation Neutron Source (SNS) and High Flux Isotope Reactor. ORNL hosts a DOE leadership computing facility, home of the Titan supercomputer; one of DOE's nanoscience centers, the Center for Nanophase Materials Sciences; the BioEnergy Science Center, one of DOE's Energy Research Centers; and the Consortium for Advanced Simulation of Light-Water Reactors, a DOE innovation hub. ORNL currently operates nine user facilities that draw thousands of research scientists and visitors each year.

\section{Sustainable Campus Initiative}

The Sustainable Campus Initiative (SCI), launched in October 2008, grew out of an earlier campus modernization program started in 2000. While SCI is an important component of ORNL's ongoing efforts to meet the requirements of Presidential Executive Order 13514, which requires government agencies to reach certain sustainability goals by 2020 , it also serves as a vehicle to communicate ORNL's sustainability achievements and demonstrate the laboratory's continuing commitment to sustainable operations.

Currently, SCI includes 25 unique focus areas (page 3) grouped according to the levels of technology required to achieve them (basic or foundational, known, leading edge, and transformational) and each assigned to an "owner" responsible for achieving the various milestones associated with the focus area.

But the program is so much more than merely an attempt to meet a federal mandate or trumpet ORNL successes. The future of this planet depends on everyone reducing his or her environmental footprint, and in reducing ours, we hope to develop methods that other organizations and individuals can benchmark. We know that communication is an important element of the program-communication and engagement with other organizations, communication with individual members of the public, and communication with our employees. 


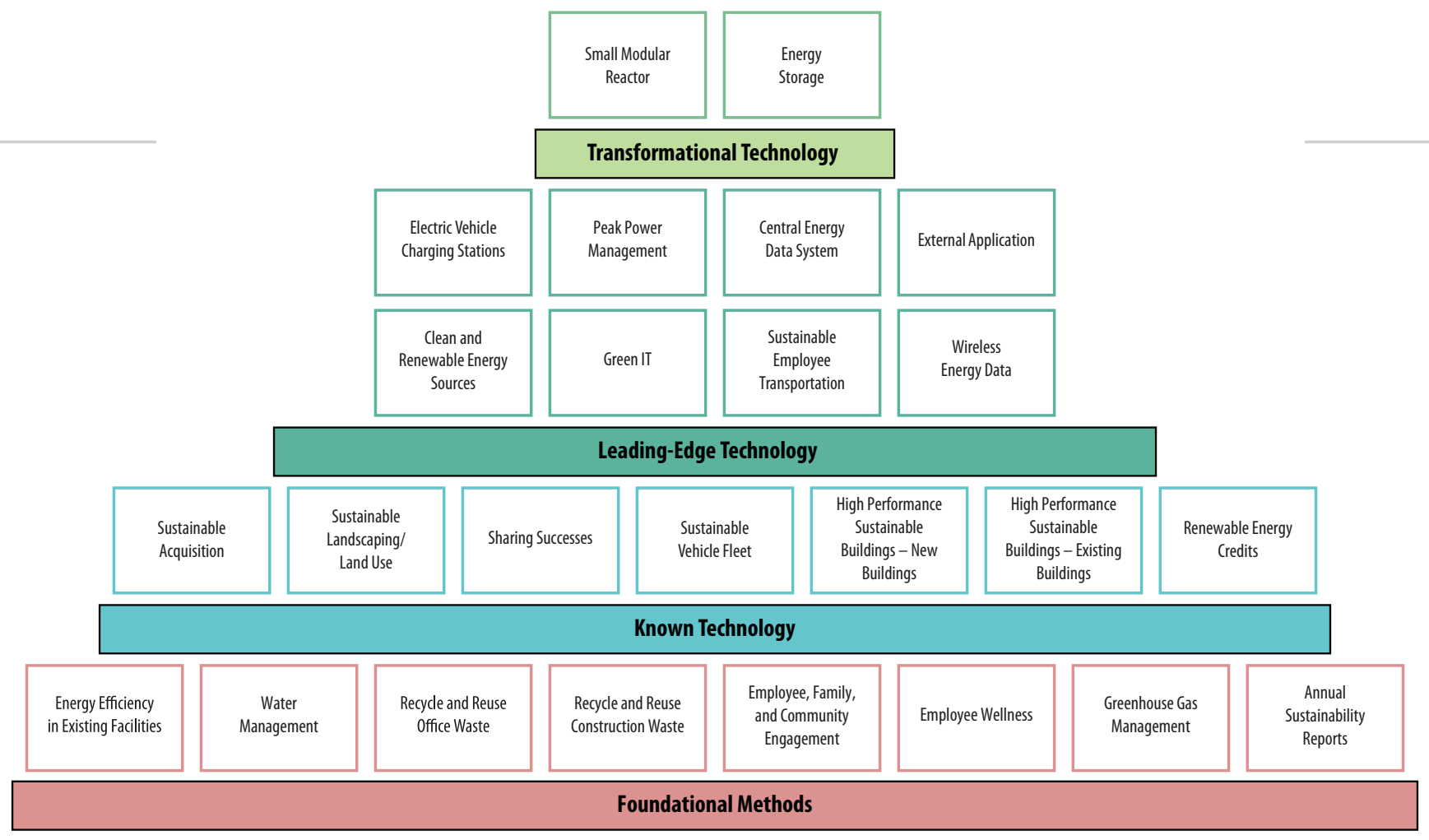

Separate but related to this, employee engagement is another important element. SCI strives to educate and engage ORNL employees so that they not only help ORNL reach its sustainability goals but also reach similar goals at home, within their families, and within their communities.

Sustainability makes good business sense. And in the course of our sustainability journey we hope to demonstrate this as well by showing that we can achieve the highest standards of sustainability, meet our research goals, and lower costs.

\section{This Report}

ORNL strives to be a leader in sustainability by embracing sustainability best practices in all aspects of laboratory operation, from research and development (R\&D) to laboratory support and maintenance functions. When SCI was established in 2008, we realized that it was not an end in itself, but rather a journey. We hope this, our second progress report, will not only provide readers with an intimate picture of where we are on that journey but also show them best practices they can use to further sustainability in their own organizations.
ORNL has achieved numerous sustainability successes since our last report such as the following, which are discussed in greater detail in this report.

- Commissioned the Biomass Steam Plant, resulting in natural gas greenhouse gas (GHG) emission reductions of $44 \%$.

- Achieved energy intensity reduction of $46.5 \%$ in 2013, exceeding the 2015 goal.

- Completed six additional high performance sustainable buildings, surpassing the FY 2015 goal 2 years ahead of schedule.

- Achieved water use reduction of $18 \%$ to date, exceeding the FY 2013 goal.

- Surpassed the goal for electric metering by achieving $90.3 \%$ of individual building metering goal.

- Received 13 external awards and certificates for sustainability achievements.

However, there are areas where we still have a ways to go, and these are discussed frankly here as well. 


\section{Energy Efficiency and Renewables}

Energy efficiency is a simple, inexpensive way to achieve some pretty important goals for our country, goals such as saving money, providing more jobs, and reducing pollution. As a national laboratory, it is incumbent on ORNL to lead the way in this and other areas of sustainability. In the following sections, we discuss how we are reaching and setting new goals and piloting technologies that others can then implement in the areas of energy efficiency and renewable energy.

\section{Energy Intensity Reduction}

When DOE set goals for GHG Scopes 1, 2, and 3 , it also set a goal for building energy intensity (measured in British thermal units per gross square foot): to reduce building energy use intensity by $30 \%$ from a FY 2003 baseline. ORNL met this goal in 2012 and continues to exceed the goal in 2013.

What makes this all the more amazing is that building gross square footage has increased astronomically during this period ( $50 \%$ over the past decade), yet ORNL was still able to achieve the goal. And the things ORNL did and is continuing to do could be applied anywhere: construction of new energy-efficient facilities, repurposing existing facilities, and demolishing inefficient legacy facilities. In addition, aggressive energy reduction activities in current facilities were combined with ongoing audits and the energy conservation measures program, new efforts in building commissioning, benchmarking energy consumption, and best management practices.

\section{Green Computing}

Computers and peripherals have become the main tools we use to conduct business in the 21st century, but it is no secret that they use a great deal of energy. In fact, in a 2003 survey the Energy Information Administration estimated that computers and office equipment accounted for $15 \%$ of the total electricity use in office buildings. While managing information technology (IT) resources can be challenging anywhere, the extensive scientific and technical needs of ORNL employees make managing IT resources here a significant challenge, and we are therefore pioneering green computing techniques that can be used here and elsewhere. These pilot programs and other IT initiatives, some of which are described in this year's report, are intended to serve as models not only for DOE, but also for other federal and private organizations.

\section{ORNL Regained Fastest Supercomputer Ranking with Titan AND Demonstrated World-Class Power Efficiency in the Process}

When ORNL's Jaguar, once the world's fastest computer, was upgraded in 2012, we were fairly certain Titan, the renamed Jaguar, would regain the title of "Home to the World's Fastest Computer" for ORNL, which it did in November 2012, demonstrating a sustained performance of 17.59 petaflops. But more importantly, total energy consumption for Titan increased by only $10 \%$ over the Jaguar system, while performance increased a full 10 -fold. The cost to operate the system, measured in terms of completed floating point operations per second per watt, puts Titan in rarified company as the third most efficient computer in the world, according to the Green500 list (http://www.green500.org). Titan produced more than 2,100 megaflops using just a single watt of electricity, exceeding the energy efficiency of previous award winners including IBM's Blue Gene/Q. In addition, 
The Verdiem Surveyor software is one example of a successful deployment based on an ORNL pilot program. The software allows us to centrally manage energy consumption of networked computers and monitors by powering down idle units into sleep and standby modes to save energy. The Verdiem Surveyor pilot program in 2009 was such a success that the software was deployed laboratorywide a year later. Today the system includes more than 7,000 desktop computers that are actively power managed, and cumulative savings since 2009 have totaled nearly $\$ 1$ million.

In late 2013, ORNL implemented a shared network printer services model to help reduce paper, toner, and power consumption. Older network printers and small desktop printers will be retired in favor of a smaller number of centralized printers. The project is slated to save ORNL more than a half million dollars per year when fully implemented, provide better and more consistent print services to users, reduce consumption of supplies, improve recycling, and provide the laboratory with more energy efficient equipment.

For the future, the IT organization is piloting a number of technologies that will allow us to replace typical desktop configurations with virtual

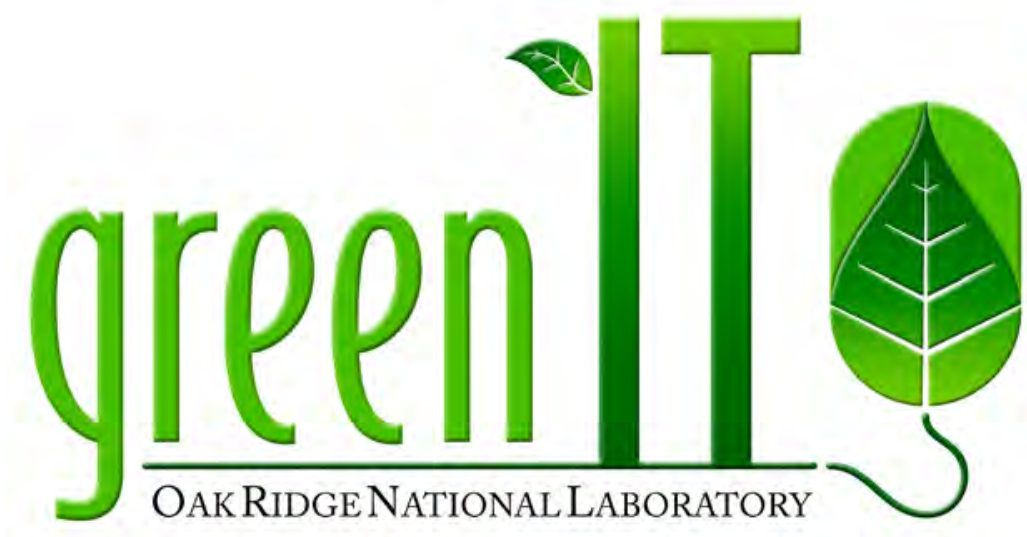

systems and applications such as "zero client," which replaces the typical desktop unit with an Ethernet connection to a remote server that hosts the user operating system. Such configurations are cheaper than typical desktop systems, use much less energy, and are easier to manage. They are also more secure. Application virtualization and data centralization are also being piloted as alternatives to traditional desktop computers. Virtual desktops will enable users to log in to any device from anywhere and view their desktops, settings, applications, and documents. The use of data centralization and desktop virtualization will empower users to become more mobile, less dependent on energy-consuming traditional computing systems, and more capable of using zero clients. Server virtualization technologies
Titan dwarfed the system capability of the two small systems that were slightly more efficient, demonstrating the ability of its hybrid architecture to efficiently scale to extremely large system size while maintaining its power efficiency. With Titan in full production, large classes of applications are demonstrating both high performance versus the nonaccelerated Jaguar system and extreme energy efficiency.

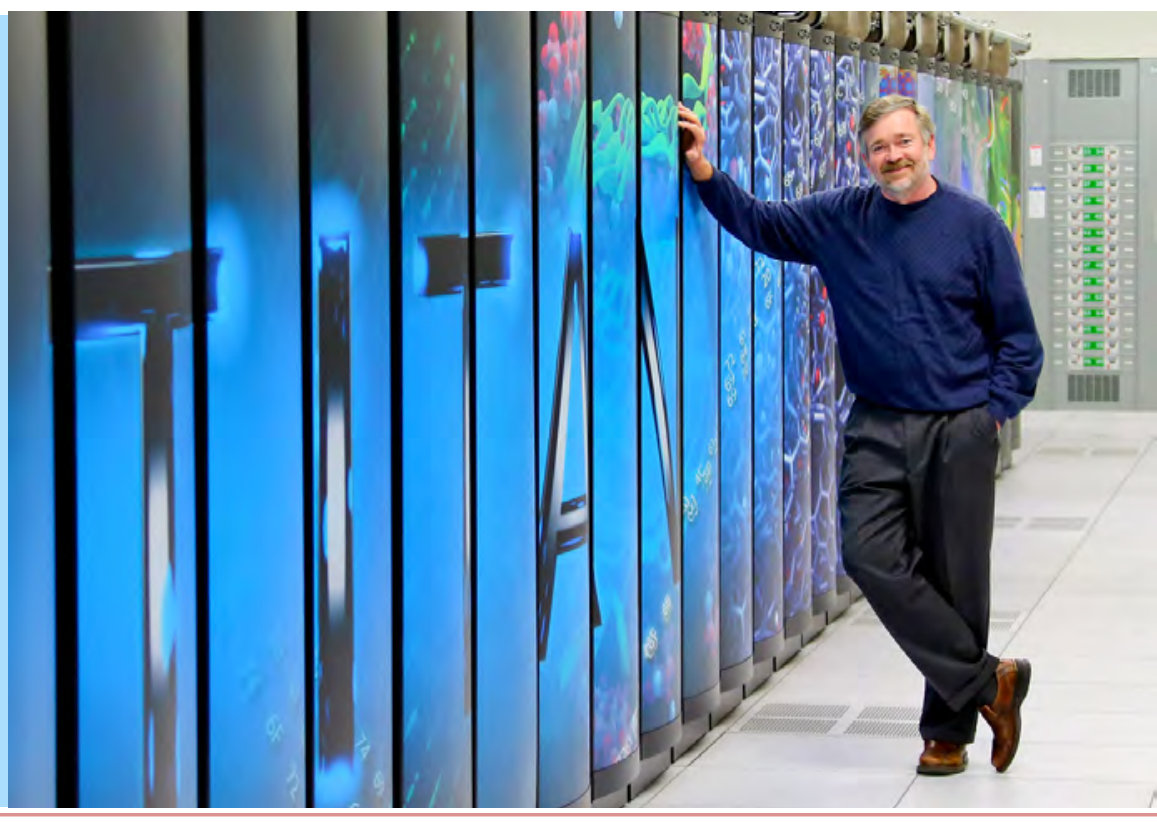


are also being piloted. Any server or application that is able to run in a virtual environment will be migrated to a centrally managed virtual server cluster. Over the next few years, all physical servers moving to the new data center will be examined to determine eligibility to move to a virtual platform, thereby excessing older equipment and improving energy and cooling savings.

\section{Utilities}

\section{Water}

Water is a precious resource worldwide, and although the United States appears to have an abundant supply, as with most resources, it is not unlimited. DOE laboratories like ORNL have a unique responsibility and opportunity to lead the way in water management strategies. And through a few simple programs, ORNL has demonstrated astounding results, exceeding the DOE goal for reduction of water use intensity (measured in gallons per gross square foot of building space).

Three types of activities have been used in ORNL's campaign to save water: domestic water conserva-

\section{Water usage decreased $54.7 \%$ $86 \%$}

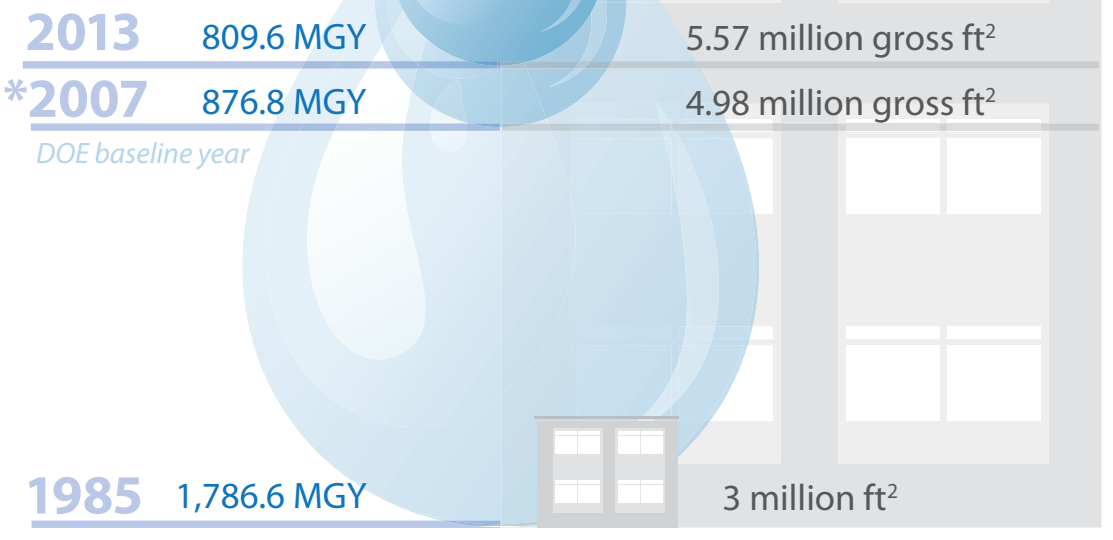

tion, elimination of once-through cooling (OTC), and repairing leaks in the water distribution system. Domestic water conservation efforts have consisted of installing low-flow devices on sinks, toilets, and showers across campus, with savings of 12 million gallons per year (MGY). Several projects have been implemented to reduce or eliminate OTC water, including installation of new closed-loop equipment with savings of 170 MGY. Repairing leaks in the water distribution system is an ongoing activity that has resulted in significant water savings both within buildings and in main distribution lines with savings of 70 MGY. Beginning in 2012 and continuing in 2013, a program directed at the entire ORNL workforce got everyone involved in finding leaks, heightening staff awareness of the need to identify and repair water leaks both at home and at work.

The results of these efforts have been nothing short of spectacular. In FY 1985 water use at ORNL was 1,786.6 MGY. By FY 2007, the baseline year for the DOE guidance for water use reduction, ORNL water use was 876.8 MGY. In FY 2013 water use was $809.6 \mathrm{MGY}$, a $7.7 \%$ reduction from the baseline year, while the building square footage had increased almost 12\% since 2007. Water use since FY 1985 has decreased an amazing 54.7\% (977.1 MGY) while the building square footage has increased $96 \%$ (2.6 million square feet). The DOE goal for water use intensity (WUI) reduction, based on Executive Order 13514 requirements, is $2 \%$ per year or $12 \%$ by FY 2013. ORNL exceeded that goal in FY 2013 with a WUI reduction of $18 \%$.

\section{Steam}

The ORNL Biomass Steam Plant (BSP), a collaborative project with Johnson Controls Inc., was commissioned in July 2012. This innovative technical application replaces most of the natural gas and fuel oil previously used by ORNL with steam created from wood chips supplied by sources within a 100-mile radius of the laboratory. BSP can produce more than 221 million pounds of steam and reduce the ORNL on-site fossil fuel consumption up to $53 \%$, resulting in operational savings up to $\$ 3.8$ million. BSP is an integral 
part of the ORNL strategy to meet our GHG emission reduction goals for on-site fuel sources (Scope 1) and contributed to the reduction of 22,700 metric tons $\mathrm{CO}_{2}$ equivalent $\left(\mathrm{CO}_{2} \mathrm{e}\right)$ of GHG emissions from the 2008 baseline year. As part of the project, the existing steam distribution system was also upgraded, including upgrades to the existing natural gas boilers, resulting in an overall improvement to the steam system. Use of biomass fuel provides a direct economic benefit to the region because the fuel source is renewable, locally grown and processed, and supplied by a number of small local businesses.

The same energy savings performance contract under which BSP was constructed included the construction of a new Melton Valley Steam Plant (MVSP), commissioned in September 2012. As part of the MVSP component of the project, a long steam distribution line from the original steam plant was removed, eliminating distribution losses and the fuel used to generate the extra steam needed to compensate for the distribution losses. Estimated savings from this are

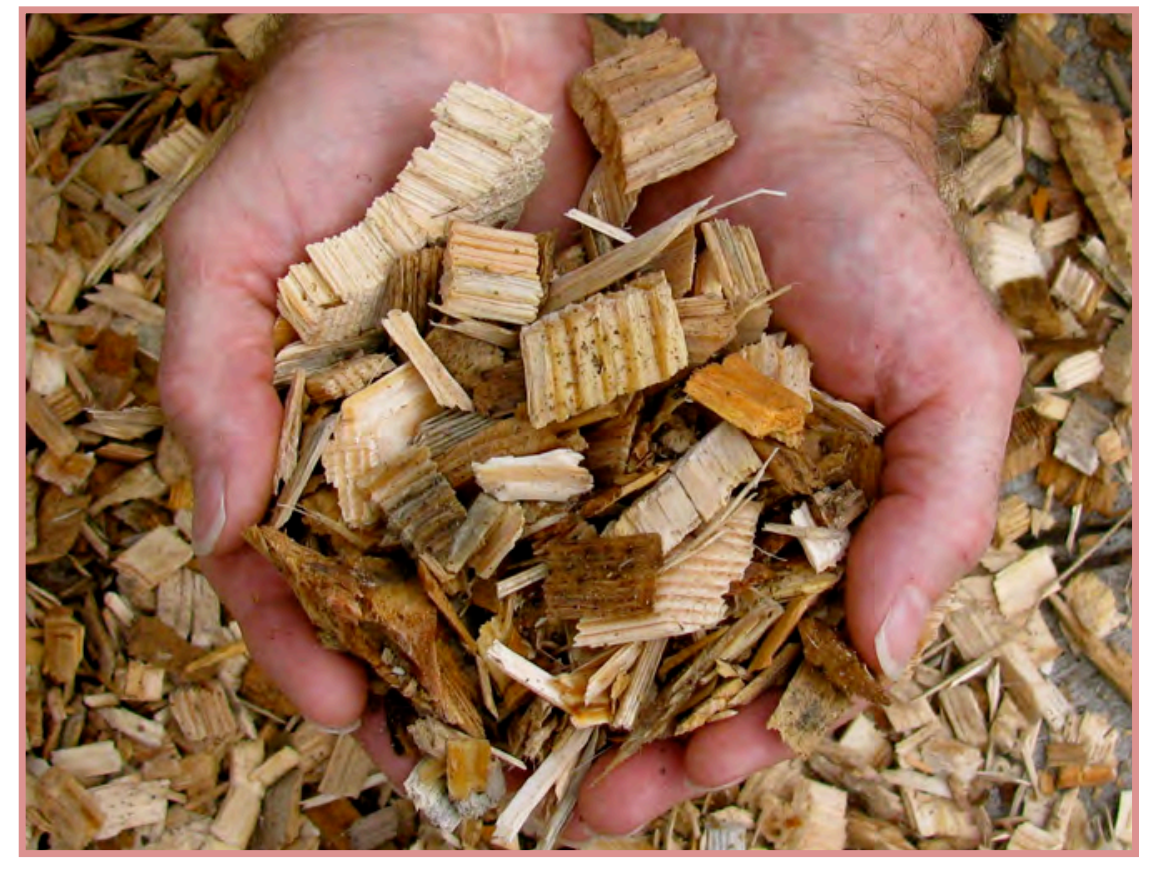

$27,584 \mathrm{MBtu} /$ year and $\$ 283,000$ annually. These natural gas savings contribute to GHG reductions of roughly 1,464 metric tons $\mathrm{CO}_{2} \mathrm{e}$.

\section{Green Lighting Options Anyone Can Use}

ORNL is constantly evaluating new projects with a view to incorporating renewable electricity wherever possible, both to further reduce our carbon footprint and to limit the number of renewable energy credits needed to reach sustainability goals. When additional lighting was needed for ORNL's beloved Swan Pond (also the recipient of recent sustainable landscaping innovations), we naturally turned to solar-four integrated 85 watt solar panels (for a total capacity of 340 watts) and three $112 \mathrm{amp}$ hour sealed gel batteries (to store energy for nighttime use and provide a buffer for cloudy days with lower charging potential). Installation was entirely in-house by skilled craftsmen from Facilities and Operations, thus saving additional expense.

The resulting system is self-sustaining; doesn't need any power from the grid; and uses long-lasting LED lamp technology, making maintenance and disposal costs lower than those for conventional lighting systems. ORNL engineers estimate that this system will save about $\$ 233$ annually compared to a conventional grid-powered system, not to mention the maintenance cost savings and greenhouse gas reductions. Additionally, the installation is a good demonstration of practical, commercially available applications of solar power technology. And the results are stunning.

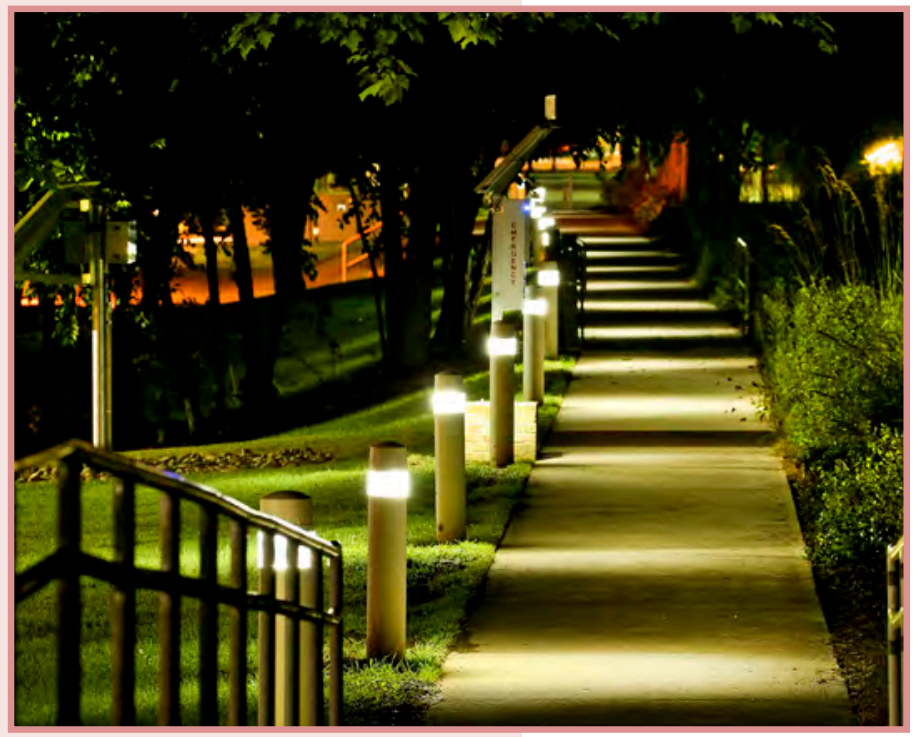




\section{Automated Monitoring for Energy Efficiency}

In FY 2013, the ORNL Central Energy Data System (CEDS) grew to about 600 smart meters, configured and reporting consumable utility data to CEDS. These consumption meters collect data on electric power, water, steam, and electric vehicles, contributing to the laboratory's smart grid and energy management capabilities. Remote control capable electric power breakers that will enhance the laboratory's smart grid capabilities were also installed. (CEDS was used to collect power consumption data for Titan.)

In addition, we have deployed an integrated CEDS EnergyCap module to facilitate providing additional electrical consumption monitoring and reporting capabilities. CEDS training, which allows access to CEDS data and the ability to view real-time, trend, and historical data, was provided for facility managers, complex managers, utility engineers, and research staff.

DOE required metering of $90 \%$ of electricity by October 2012 and requires $90 \%$ metering of steam, natural gas, and chilled water by October 2015. We have already exceeded the goal for electricity (currently $90.3 \%$ metering) and natural gas (currently 94.4\%) and are progressing on chilled water and steam metering. CEDS and the smart meters and advanced sensors currently being developed and implemented will serve as valuable tools for ORNL's continuous efforts to better understand utility consumption and track conservation and potentially will enable demandside management in the future.

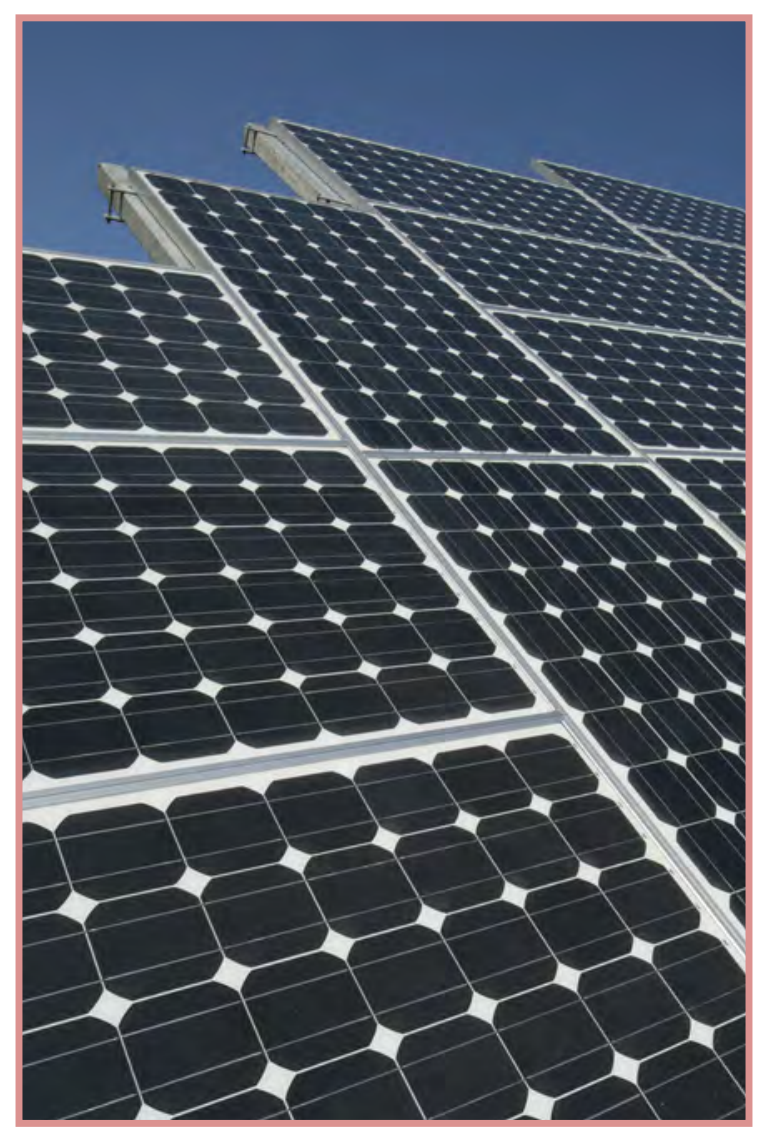

\section{Renewable Energy}

DOE's goal for FY 2013 is 7.5\% of annual electricity consumption from renewable energy sources. As a result of a recent change from the President, the goal has been increased to $20 \%$ by FY 2020. Multiple sources of renewable energy are used at ORNL. The electricity produced on-site from four solar arrays accounted for about $250 \mathrm{MWh}(0.024 \%)$ of electrical consumption at ORNL. Another $338 \mathrm{MWh}$ was purchased through TVA's Green Power Switch Program. ORNL also purchased 3,000 MWh of Renewable Energy Credits (RECs) from TVA's Southeastern REC Pilot and another 53,948 MWh of RECs on the open market. The total renewable sources at ORNL in FY 2013 was 57,558 MWh or 10\% of the total electrical consumption, exceeding the $7.5 \%$ DOE goal for FY 2013.

The laboratory is constantly evaluating new sources of renewable electricity to limit the number of RECs needed to reach sustainability goals. 


\section{Piloting Transformational Technologies for Sustainability}

At one time, taking a trip in the family car could be fraught with uncertainty: range anxiety, a fear of running out of fuel, was a real concern. Well, that time is here again for drivers of plug-in electric vehicles (PEVs): charging stations aren't exactly ubiquitous yet. Couple this with complaints about forgetting to charge and the hassle of performing the necessary operations in inclement weather, and you have sufficient barriers to hinder penetration of the vehicle market by PEVs.

A team at ORNL is working with collaborators from industry, universities, and electric utilities to resolve this problem with a technology known as wireless power transfer (WPT), charging plug-in vehicles without the need for cables and plugs while the vehicles are stationary, in stop-and-go mode, or even while in motion. Once implemented, WPT will enable smaller, lighter batteries, lowering the cost and weight of electric vehicles and increasing their efficiency and reliability. Combined with wireless communications, a truly autonomous charging technology can be deployed that removes the vehicle operator from the loop. The technology will also enable future innovations such as automatic positioning, obstacle detection, and utility time of use and rate structures, and other convenience features that are only beginning to surface. Best of all, it will allow electric cars to become as ubiquitous, and well-loved, as gasoline-powered vehicles in the last century.

At present, ORNL staff are retrofitting a Prius that was used on a previous research project with a wireless power transfer (WPT) system. The retrofitted Prius will be used on-site by the ORNL mail services staff to deliver mail to on-site and off-site locations such as SNS, Commerce Park, and the National Transportation Research Center. The retrofitted Prius will have the WPT system installed underneath the car, and this will allow the Prius to be charged at the on-site charging station at the ORNL Main Campus Mail Services Building.
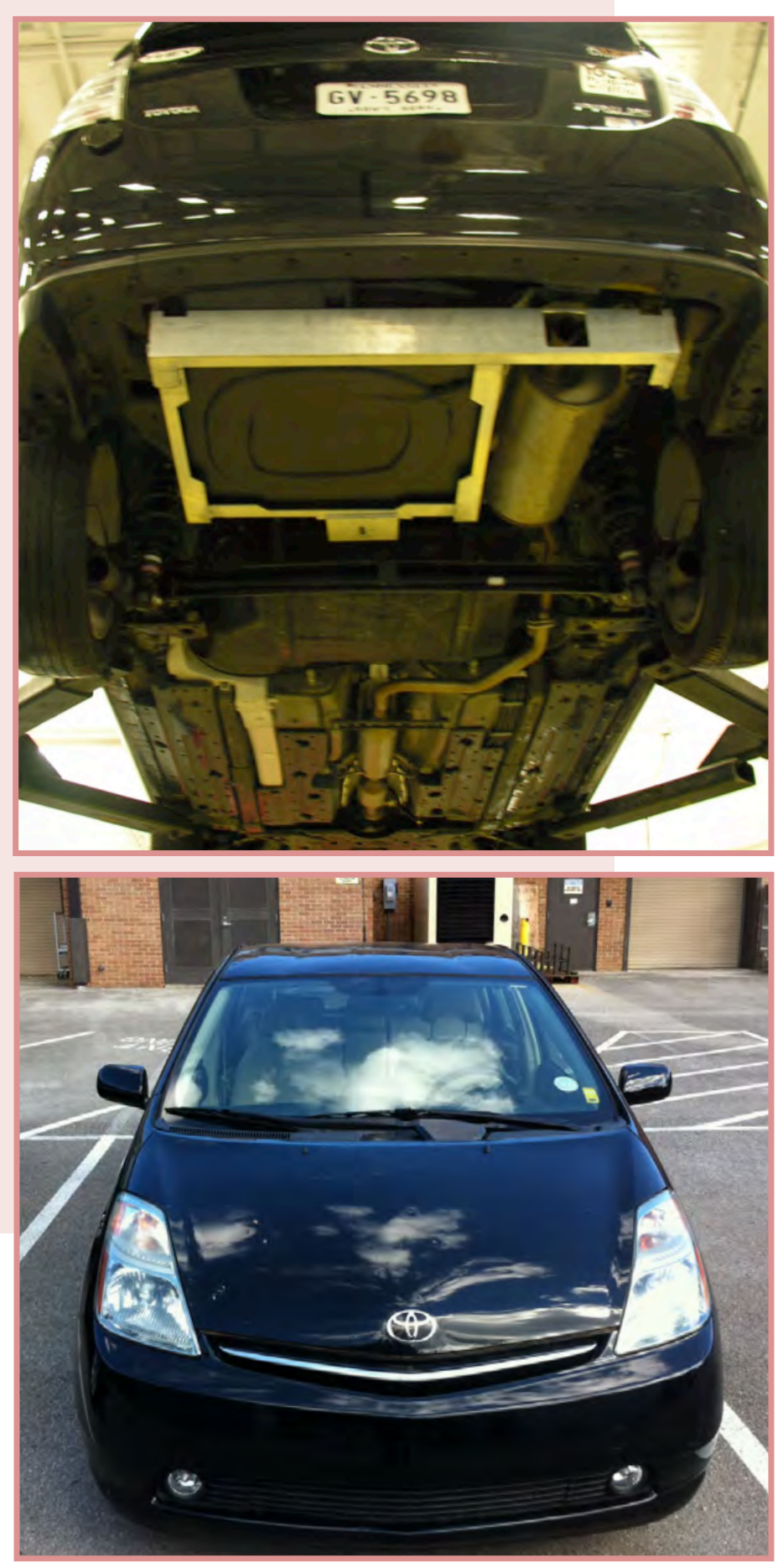


\section{ORNL Leads in \\ LEED Certification}

Seventy years after its establishment, ORNL has been transformed from a single-purpose facility to a center for multiple world-leading scientific research initiatives. Over the last decade, major science program investments, including the $\$ 1.4 \mathrm{~B}$ SNS and more than $\$ 750 \mathrm{M}$ in modernization projects, have produced a modern, worldclass research campus. All new construction, major renovations, and alterations of buildings greater than 5,000 gross square feet (gsf) comply with the High Performance Sustainable Building
(HPSB) guiding principles. Currently, ORNL has 23 HPSBs, which include four buildings retrofitted and two buildings constructed in FY 2012. ORNL has one of the largest collections of LEED-certified buildings on a single campus in the entire Southeast with a total of six LEED Gold and two LEED silver facilities. In FY 2013, ORNL received LEED Gold certification for one newly constructed building which resulted in exceeding our FY 2015 goal of 22 HPSBs a full 2 years ahead of schedule.

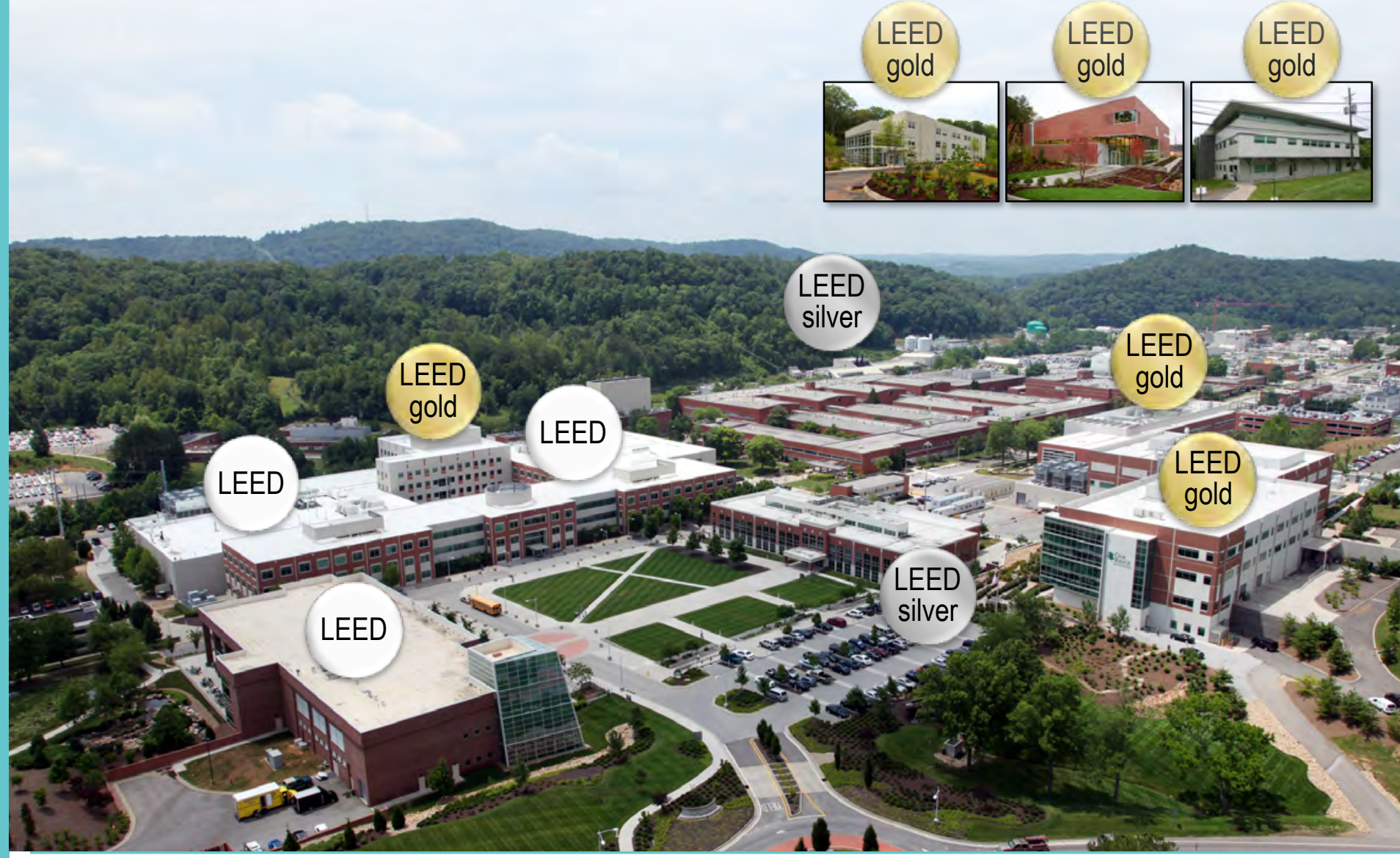




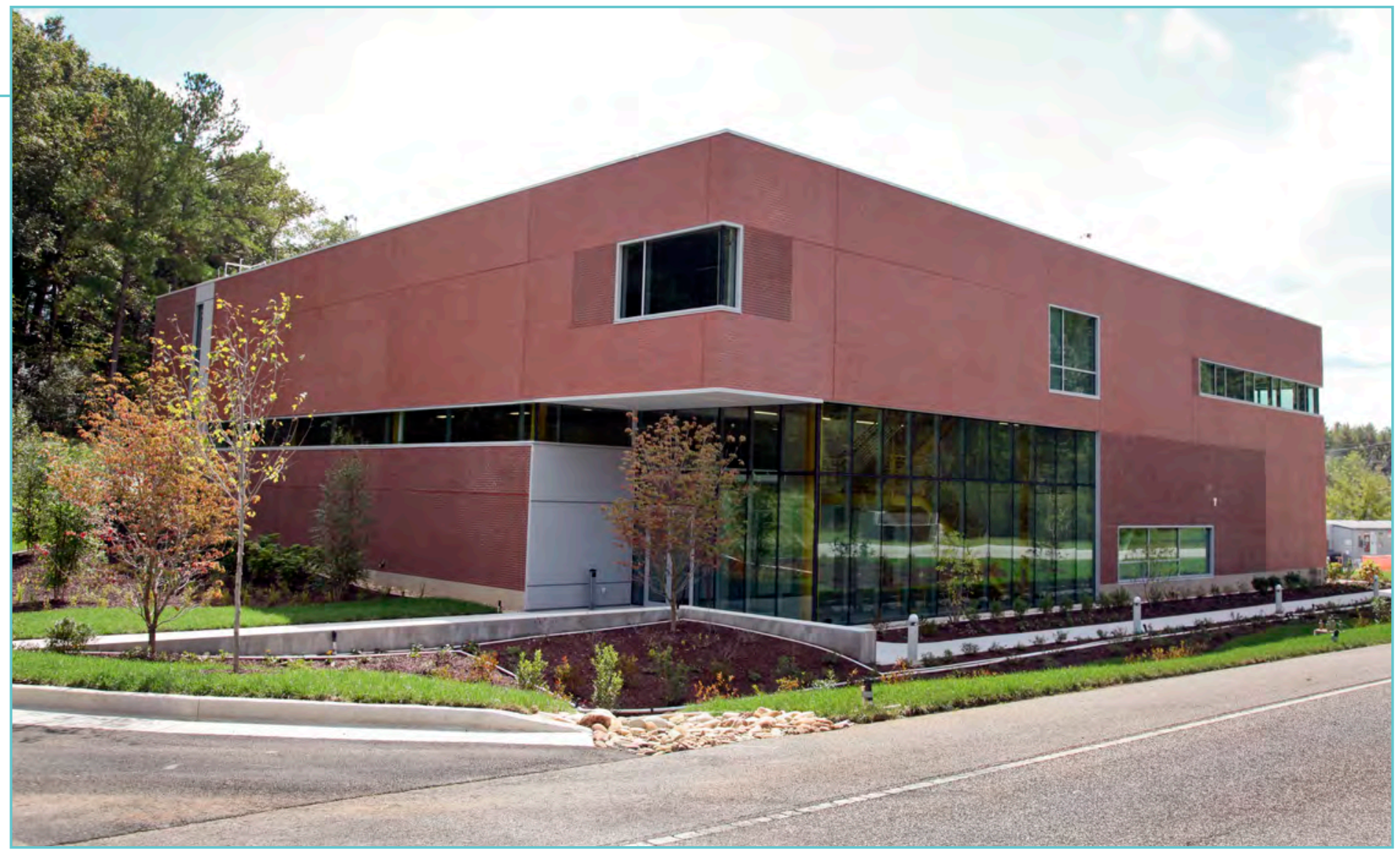

Construction successes in 2012 included completion of the Maximum Energy Efficiency Laboratory, or MAXLAB. The $\$ 16$ million, 18,000 gsf MAXLAB received its LEED Gold certification based on a number of green construction and operation features, including a rainwater harvest tank; motion sensors; use of day lighting in interior laboratory space; thermally improved cool roof technology; thermally improved precast sandwich panel building envelope; aluminum exterior sunshades; $26 \%$ increased energy efficiency over the American Society of Heating, Refrigerating and Air-Conditioning Engineers baseline model; and individual thermostat controls in each office.

Modernization successes in 2012 included multiple site infrastructure modernization projects, renovations, upgrades, and office improvements.
Winning the 2013 Federal Energy and Water Management Award is a strong indicator of SCl's success on campus. The new partnerships that have developed from our researchers and facilities teams working together toward sustainability goals have been a strategic strength for ORNL.

- Martin Keller, Associate Laboratory Director, Energy and Environmental Sciences Directorate, and Cosponsor of ORNL's Sustainable Campus Initiative 


\section{Fleet Management}

Wise fleet management is a critical part of the ORNL sustainability strategy. Through intelligent fleet use, rightsizing, and a successful combination of fleet petroleum use reductions, fleet alternative fuel increases, and purchase of alternative fuel vehicles, ORNL continues to meet or exceed federal fleet sustainability goals.

Fleet rightsizing is a management tool that can help organizations build and maintain fleets of fuel-efficient vehicles by excessing older, rarely

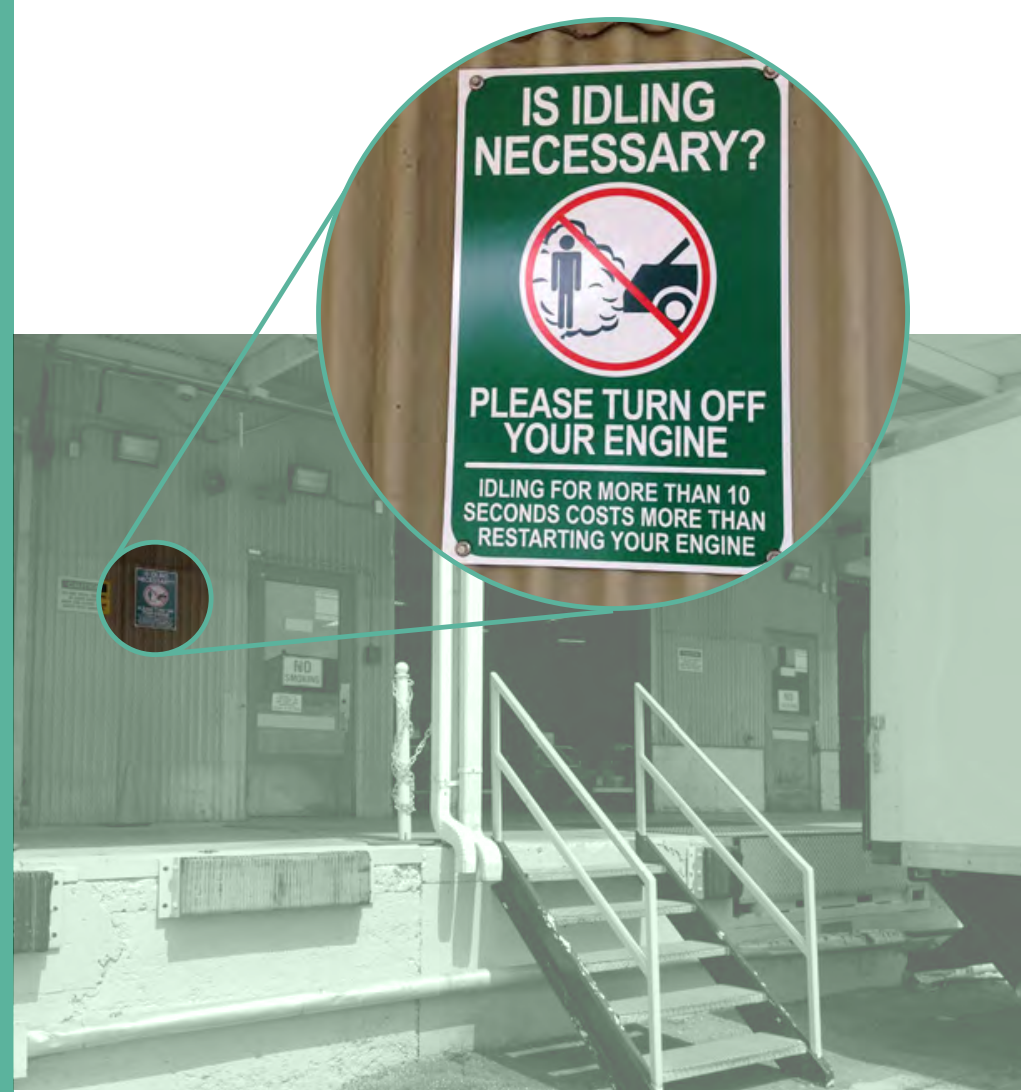

used, and/or inappropriate vehicles. Rightsizing can also help minimize vehicle use, conserve fuel, and save money.

\section{In 2012, ORNL submitted a fleet rightsizing} management plan to DOE and was thus able to reduce the fleet by 58 vehicles, or $12 \%$. As a result of rightsizing and a goal to make alternate fuel vehicles $100 \%$ of light duty purchases by 2015 , flexible fuel vehicles (FFVs) now make up 58\% of the fleet, and low-speed electric vehicles (EVs) make up $10 \%$ of the fleet. In addition, the fleet also comprises $38 \mathrm{EVs} /$ hybrid EVs, including 2 hybrid diesel buses.

Through communication, driver training, and rapid response to any fuel quality issues, the fleet FFVs achieved a 68\% E85 use rate in 2013. For reduction of petroleum based fuel consumption, ORNL achieved a 53\% reduction from the 2005 baseline which exceeds the required target of a $16 \%$ reduction. Additionally, through carefully monitoring trips, trip routes, etc., fleet vehicle miles were reduced by $19 \%$ between 2012 and 2013.

Because it has been well-established that idling vehicles results in wasted fuel, negatively impacts the environment, and can lead to increased maintenance costs, ORNL worked with the local DOE Clean Cities program on a campaign to reduce idling of ALL on-site vehicles, including developing an idle reduction guide (http://sustainability-ornl.org/documents/ ORNL\%20Idle\%20Reduction\%20Guide.pdf) with a collection of vehicle manual excerpts explicitly recommending against idling. As part of the campaign, anti-idling signs were placed at loading docks throughout the laboratory. The idle reduction guide has been made public and publicized to employees in articles on the benefits of idle reduction. 


\section{Reaping the Green Benefits of Wise Fleet Management}

A unique opportunity for teamwork paved the way for the ORNL Transportation Management organization to significantly modernize its passenger tour bus operations while saving money AND cutting GHG emissions.

ORNL hosts hundreds of tours each year. Last year alone there were more than 400 bus tours. Those tours add up to a lot of fossil-fuel-gobbling miles and air-polluting emissions. As a result of collaborations between DOE, ORNL, and the Idaho National Laboratory (INL) Integrated Transportation Services organization, ORNL is now the proud owner of two diesel hybrid passenger buses. The newly acquired buses achieve more than twice the miles per gallon of their predecessors and, with hybrid technology, minimize emissions.

INL purchased the diesel hybrid buses in 2010; however, INL has dramatically changed its bus system since then, rendering the two diesel hybrids superfluous in the process. ORNL Transportation Management had just put in an order for one new passenger bus when staff members learned about the surplus buses during a benchmarking trip to INL, which started the wheels in motion.

Teamwork among the DOE Office of Science Integrated Support Center, Idaho Operations Office, and the two laboratories was crucial in working out the details required to transfer the buses. It all came together, saving taxpayers more than $\$ 300,000$ and providing ORNL not one but two fuel-efficient hybrid buses.

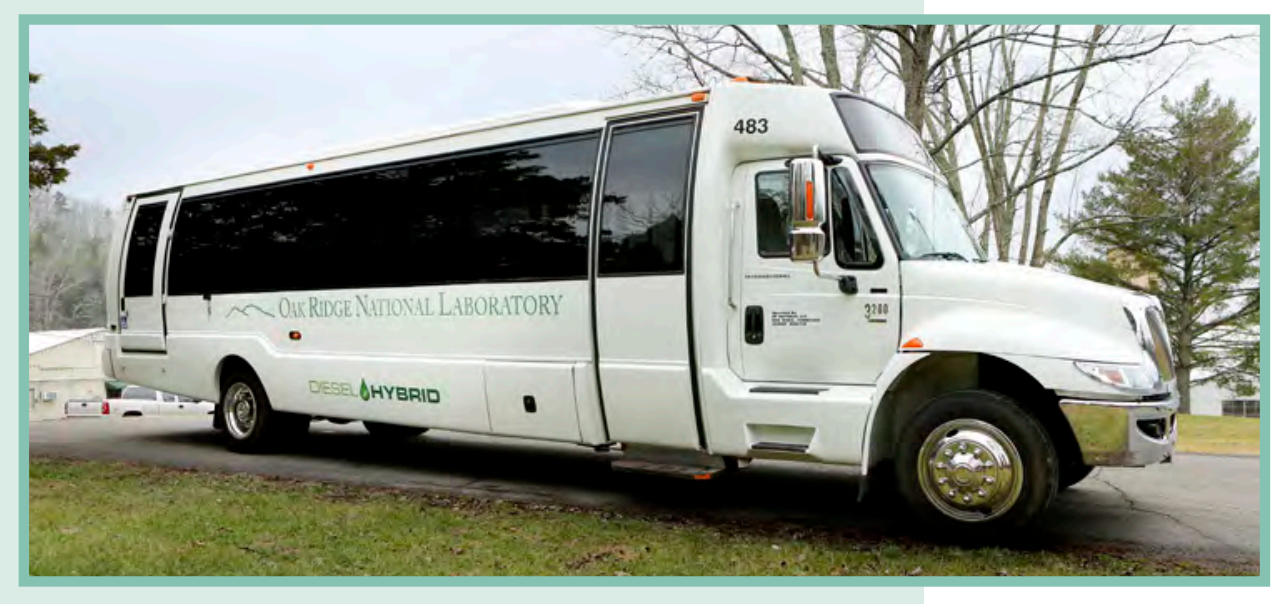

\section{Employee Commuting}

Establishing a sustainable campus at ORNL includes the creation and implementation of transportation action programs that provide employees with more commuting choices and encourage use of smarter commuting options (in both their work and personal lives), thus reducing employee contributions to traffic congestion and air pollution and saving employees money at the same time. ORNL encourages a wide variety of alternatives to traditional commuting, including car-/vanpooling, bicycle commuting, telework, and compressed or alternate work week schedules that lead to fewer commuting trips, and supports such choices through internal communications, internal policies and procedures, and the ORNL SuperCommuter website.

\section{In 2012 the ORNL Transportation Council} was established as a mechanism to coordinate employee commute options and services. Since then, the council has successfully worked on issues such as developing mechanisms to track 
the number of people who are teleworking and using alternative work week arrangements and tracking use of teleconferencing to avoid business travel. In addition, council members worked successfully to reinstitute two-person carpool parking (see below) to further incentivize carpooling in 2014.
Recognizing that car-/vanpooling is the backbone of any strong alternative commuting program,

ORNL has formally supported car-/vanpooling for more than 7 years, providing support services and amenities to encourage carpooling such as participation in The Knoxville Regional Transportation Planning Organization's free Smart Trips

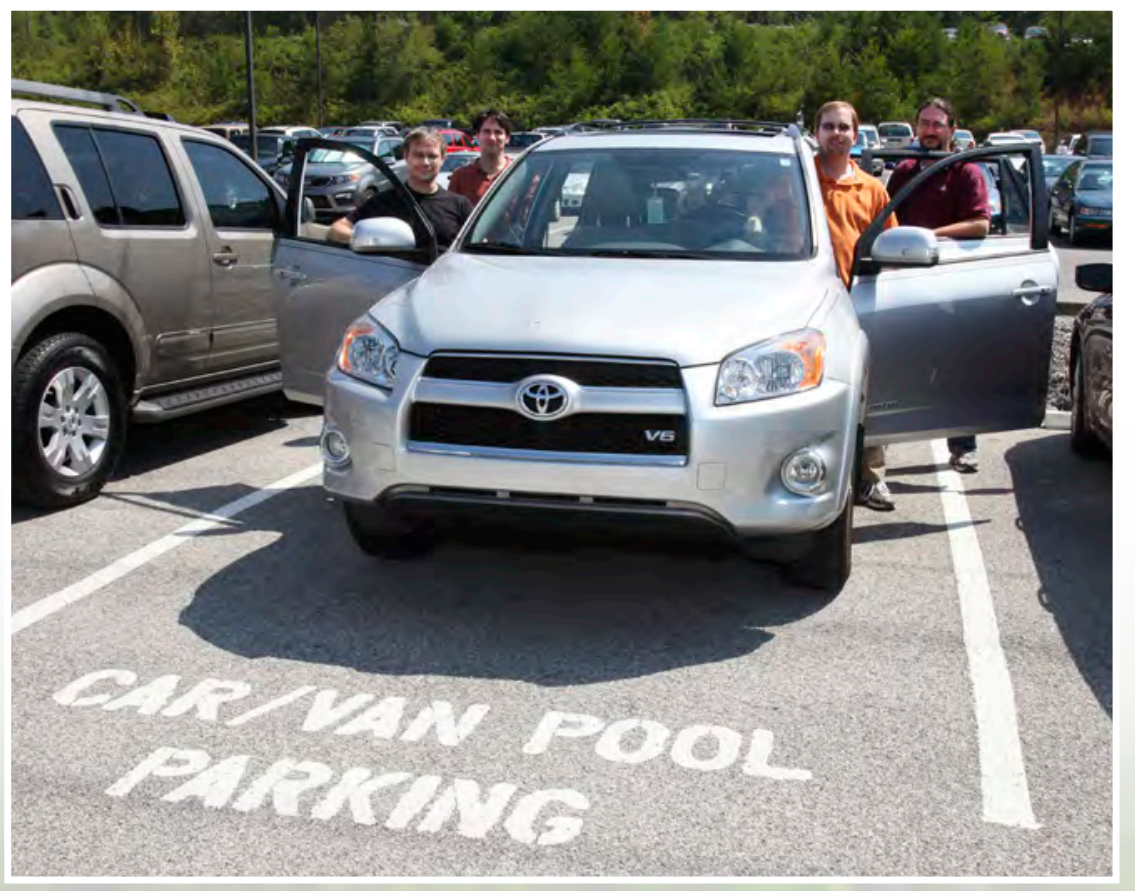


rideshare program. This past year a decision was made to discontinue the ORNL ridematch site in favor of having just one site through the Smart Trips program to strengthen our partnership with the program, reduce duplication, and streamline the system for employees. As a result of this change and associated promotional efforts, ORNL participation increased 21\% in 2013.

During the next year, priority parking for two-person carpools will be added to the ORNL Employee Commute Program. The new policy will be promoted to employees, and results should be seen soon thereafter based on the expected popularity of the two-person carpools. Applicants for priority parking spaces will be strongly encouraged to sign up for the Smart Trips program to log their travel. Also, potential park-and-ride locations have been surveyed in the city of Oak Ridge to create convenient gathering places for carpoolers, and the city has committed to working with ORNL to obtain permission for use of an area for carpoolers.

\section{Regional Transportation Coordination}

ORNL and SCI actively engage in regional and local planning for sustainable transportation as well as outreach activities for the enhancement of sustainable transportation in the entire southeast region. In 2013, SCI coordinated with regional efforts to create more effective, efficient, and affordable regional travel options, including coordinating with local, state, and federal telecommute and rideshare initiatives. Specific efforts included

- expansion of Smart Trips participation,

- participation as a member of the Knoxville Regional Transit Development Plan process to expand transit opportunities across the region and in the Pellissippi Parkway corridor,

- participation in the US Department of Housing and Urban Development-US Department of Transportation Regional Sustainable Development Consortium (PlanET), and

- coordination of ORNL sustainability efforts with the efforts of the PlanET member communities and consultants.

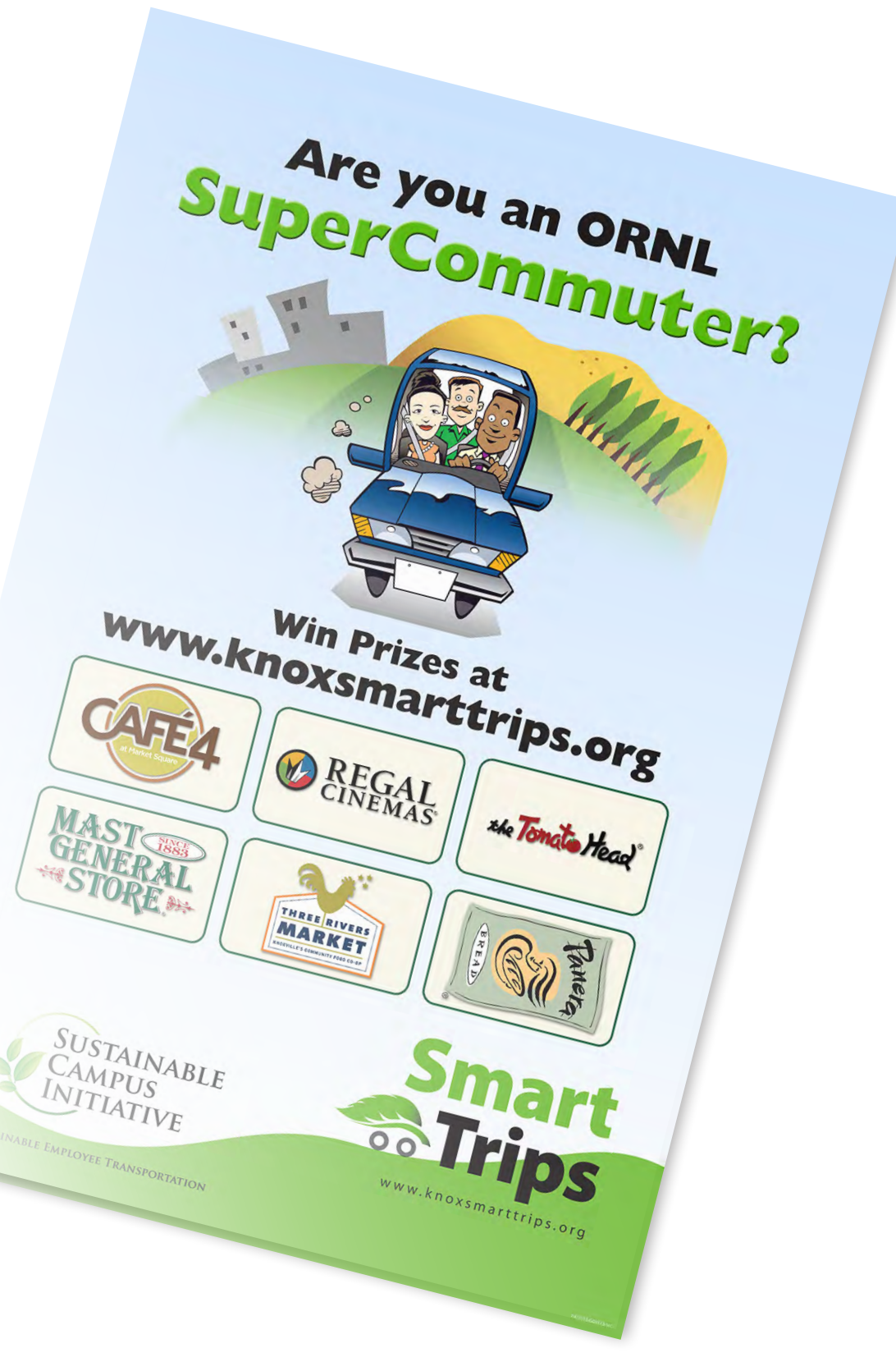




\section{Pollution}

\section{Prevention}

The Pollution Prevention Program at ORNL strives to conserve resources and reduce the cost of R\&D activities by developing and implementing techniques, technologies, and programs that minimize waste and pollution. From FY 2009 through FY 2012, new pollution prevention initiatives eliminated about 2.6 billion pounds (1.3 million metric tons) of waste, with an associated cost avoidance of more than $\$ 23$ million.

Each year ORNL's Property Disposition Program prevents millions of dollars of usable equipment, furniture, and supplies from being sent to a land- fill. Through its Reutilization Program, unwanted furniture and equipment can be given a new home at another ORNL office or DOE facility. During FY 2012 alone, ORNL reused more than $\$ 13$ million of materials and equipment through redeployments, donations, and transfers and sold to the public more than $\$ 1$ million of government property no longer needed by ORNL or DOE. One example is the Computers-for-Learning Program, which provides excess working computers and related equipment to primary and secondary schools throughout the state. (Nonworking equipment is sent to a qualified recycler.) In addition, ORNL supports the Energyrelated Laboratory Equipment Grant Program established by DOE to donate available used equipment to institutions of higher education for energy-related research.

\section{Giving New Meaning to the Saying "One Person's Trash Is Another's Treasure"}

Containers and packaging make up more than $30 \%$ of all municipal waste-up to 76 million tons per year. One recent example is ORNL's Titan supercomputer, whose components were delivered in more than 200 containers of packaging foam. ORNL's Excessing and Property Sales organization (E\&PS) is doing its part to reduce this and other waste: In 2012 alone, E\&PS donated, transferred, and sold property totaling almost $\$ 12$ million, substantially reducing the ORNL waste footprint.

Selling the Titan foam packaging for reuse is just one of many recycling and reuse initiatives pursued by E\&PS each year. Rather than sending damaged furniture to the landfill, E\&PS awards an annual contract to an individual who either repairs for resale or recycles the damaged furniture, with annual cost avoidances of about $\$ 30,000$ in addition to the landfill loads avoided. The ORNL group also contracts for used oils recycling, avoiding expensive on-site processing and the potential risks to ORNL employees. Thanks to E\&PS efforts, in 2012 ORNL sold the following recyclables:

- more than 270 tons of scrap metal,

- 20,000 pounds of used batteries, and

- 31,000 gallons of used oils,

- 97,000 pounds of electronics.

- 700 used tires,

In addition to cost and landfill avoidances, because of E\&PS efforts ORNL was also able to make property donations of almost $\$ 2$ million to schools and nonprofit organizations last year. 


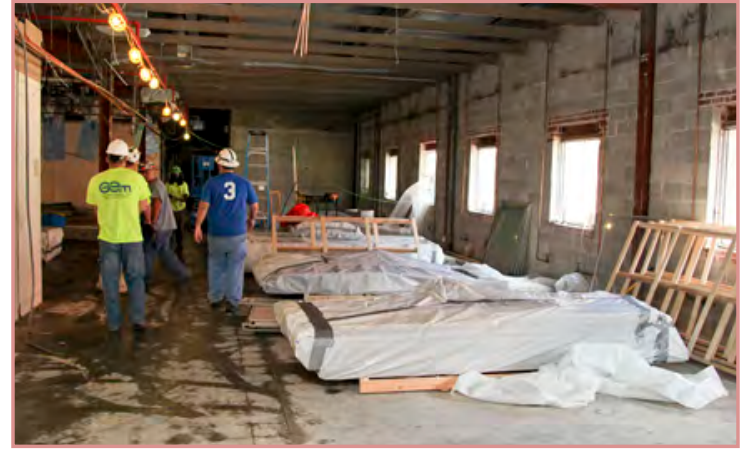

Municipal, Construction, and Demolition Waste

Having set goals of reducing municipal solid waste and construction and demolition waste sent to a local landfill by $50 \%$ by 2015 , in 2010 program staff conducted extensive surveys to ascertain on-site waste characteristics and employee waste disposal and recycling practices. As a result of these surveys, measures were implemented to make reducing waste and recycling not only easier for employees, but also more thoroughly a part of our corporate culture. Because of these and other efforts, in FY 2013 ORNL diverted $34 \%$ of its municipal solid waste from the landfill. Although this is still below the $50 \%$ target for 2015 , we continue to achieve increased diversion rates compared with the $27 \%$ realized in 2010 .

Contracts for new construction always address the recycling of excess building material, but before 2011 waste generated from the remodeling of existing structures went to a landfill. A contract was subsequently put in place to recycle a large portion of waste materials resulting from remodeling. In FY 2012, 78.6\% of the construction and demolition waste was diverted from the landfill, thus exceeding the waste reduction goal for 2015. Due to a much smaller demolition program in FY 2013, ORNL's construction and demolition diversion rate was $39 \%$.

\section{Continuing Efforts}

ORNL is always searching for new ways to reduce the amount of municipal, construction, and demolition waste it generates. Thirty-seven new pollution prevention projects were implemented during 2012, eliminating more than 51 million kilograms (about 114 million pounds) of waste, including about 11.8 million gallons of wastewater. Excluding the wastewater efforts, these projects eliminated about 7 million kilograms (about 15 million pounds) of waste. In total, all of these projects led to cost savings/avoidance of more than $\$ 8$ million (including ongoing reuse/ recycle projects). Source reduction actions such as efforts related to medical radioisotopes; resource efficient supercomputing; and recycling programs for led, electronics, and construction and demolition debris were also implemented during 2012. As a result of the recycling program at ORNL, more than $68 \%$ of FY 2012-generated municipal and construction and demolition wastes were diverted for recycle or beneficial use. 


\section{Greenhouse Gas}

\section{Management}

Since DOE established GHG emission goals for Scope 1 (direct emissions), Scope 2 (indirect emissions such as those resulting from sources of purchased energy), and Scope 3 (all other indirect emissions such as those from employee commutes) emissions, ORNL has evaluated GHG inventories annually. From the time ORNL conducted its first comprehensive GHG inventory, our goal has been to support projects designed to meet or exceed DOE GHG reduction targets. The BSP project is an excellent example of this. In FY 2013, the first full year of savings from the BSP project, natural gas use has decreased from $10 \%$ of our GHG inventory to $7 \%$. This and other efforts helped to exceed the Scope 1 reduction target of $28 \%$. Overall, Scope 1 GHG emissions are down 51\% - again, ahead of the target set for 2020 .

However, Scope 2 and Scope 3 emissions, over which ORNL has less direct control, are somewhat more problematic. The primary sustainability challenge continues to be electricity consumption forecasts associated with the

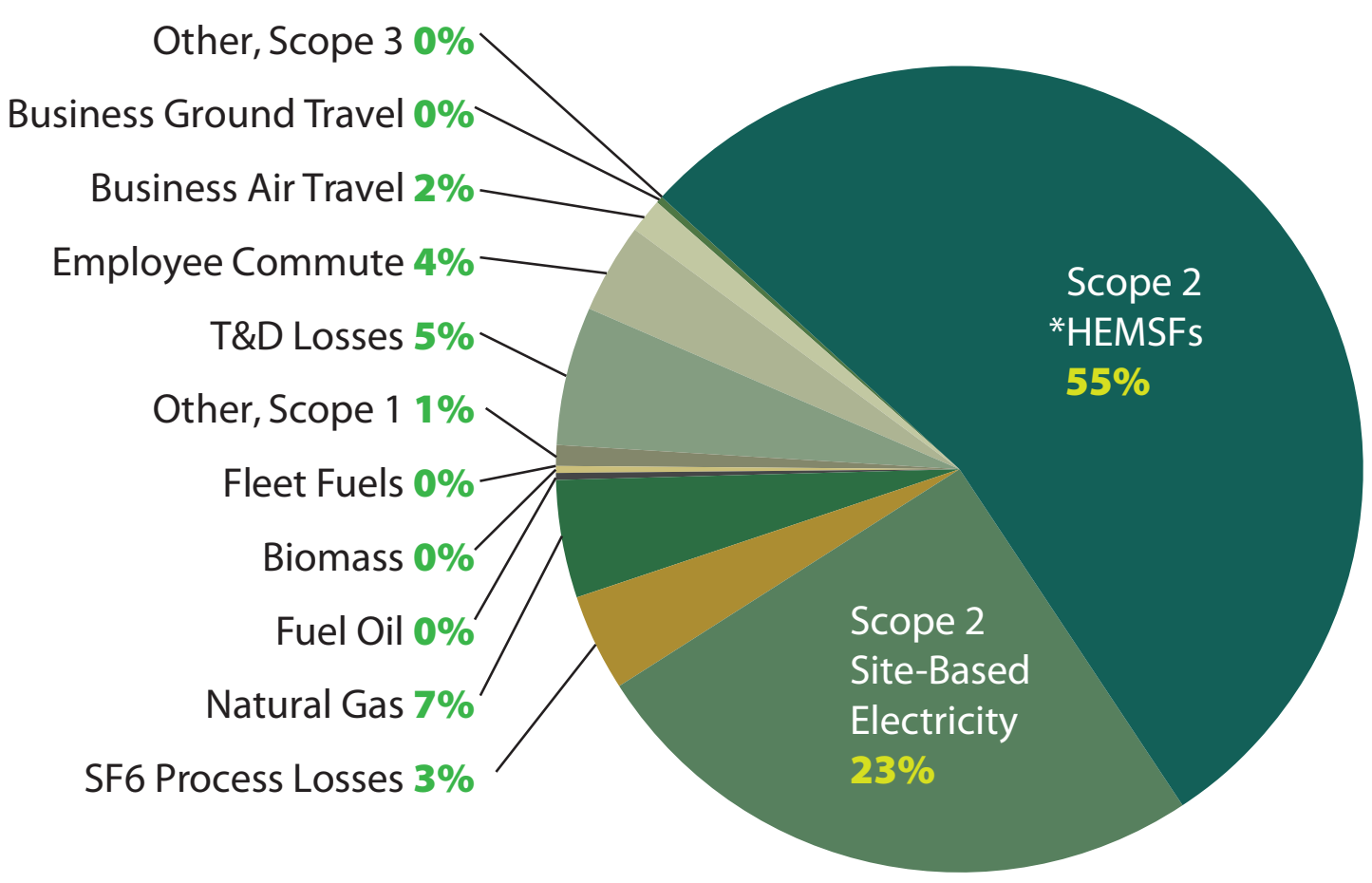

*High Energy Mission Specific Facilities (HEMSFs) 
operation of our high energy mission specific facilities (HEMSFs). DOE has acknowledged that HEMSFs at the department's national laboratories play an essential role in the fundamental $R \& D$ necessary for the scientific breakthroughs that will increase our energy independence and national security. As these programs grow, electricity use will continue to increase. This increase has resulted in a Scope 2 inventory that has grown to $78 \%$ of the total GHG inventory. Due to the growth of HEMSF operations, total electricity purchases are currently $60 \%$ greater than the GHG baseline year of FY 2008.

The reduction of GHG emissions from purchased electricity and the related transmission and distribution (T\&D) losses (Scope 3) is dependent upon our engagement with our power provider, the Tennessee Valley Authority (TVA), to establish clean power production goals and to upgrade the T\&D infrastructure. ORNL has a strong working relationship with TVA, and we continue to influence decisions that will result in improved operations. ORNL has taken a proactive position, including putting TVA on our solutions team for Scope 2 GHG reductions, and we are working with them to influence lower carbon content in transmitted electricity in our region. The transformational small modular reactor, a project that will result in cleaner power production for the entire region, is an example of the technology that ORNL is interested in supporting to achieve GHG reductions needed to meet Executive Order 13514 mandates by 2020 .

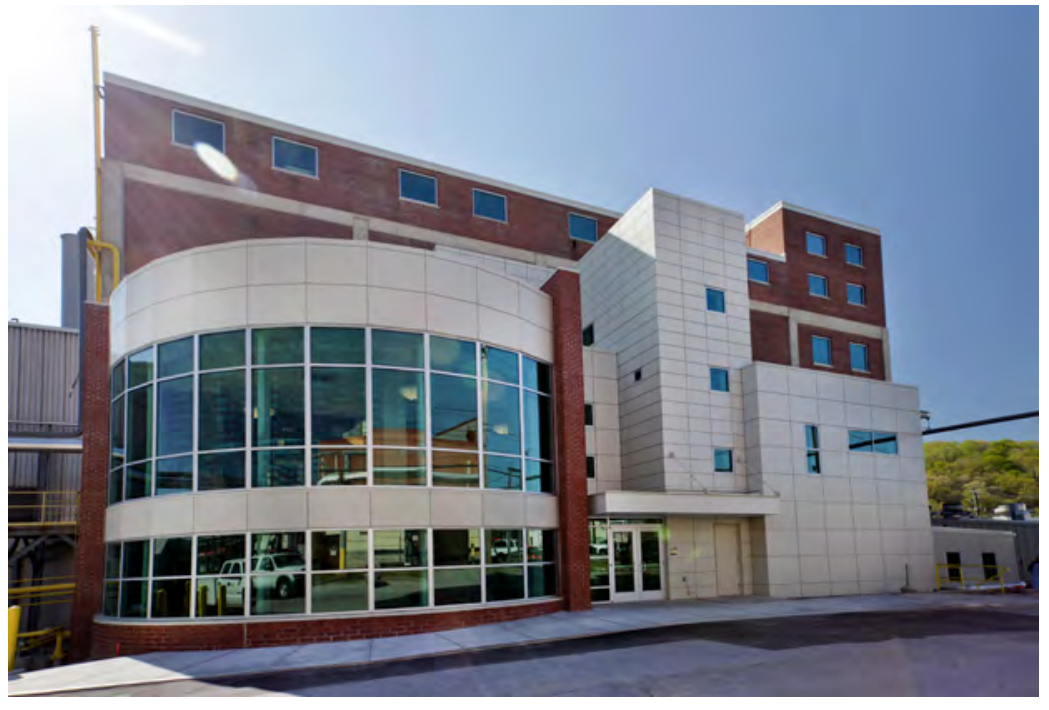




\section{Safety, Health, and Wellness}

ORNL history. A strong trending and communication process continues to improve safety awareness and address emergent issues. The total

\section{Environmental and Safety Performance}

Environmental and safety performance are critical elements in the quest for sustainability. They include the responsibility to protect the health, safety, and well-being not only of our employees, but also of the environment, customers, and those in neighboring communities. From FY 2012 to date, ORNL's performance in this area has been outstanding. The environmental permit compliance rate was greater than $99.9 \%$, there were no reportable releases to the environment, and no findings were reported during inspections conducted by regulators.

Injury performance at ORNL continued to improve during FY 2013, which resulted in the lowest number of recordable injury cases in

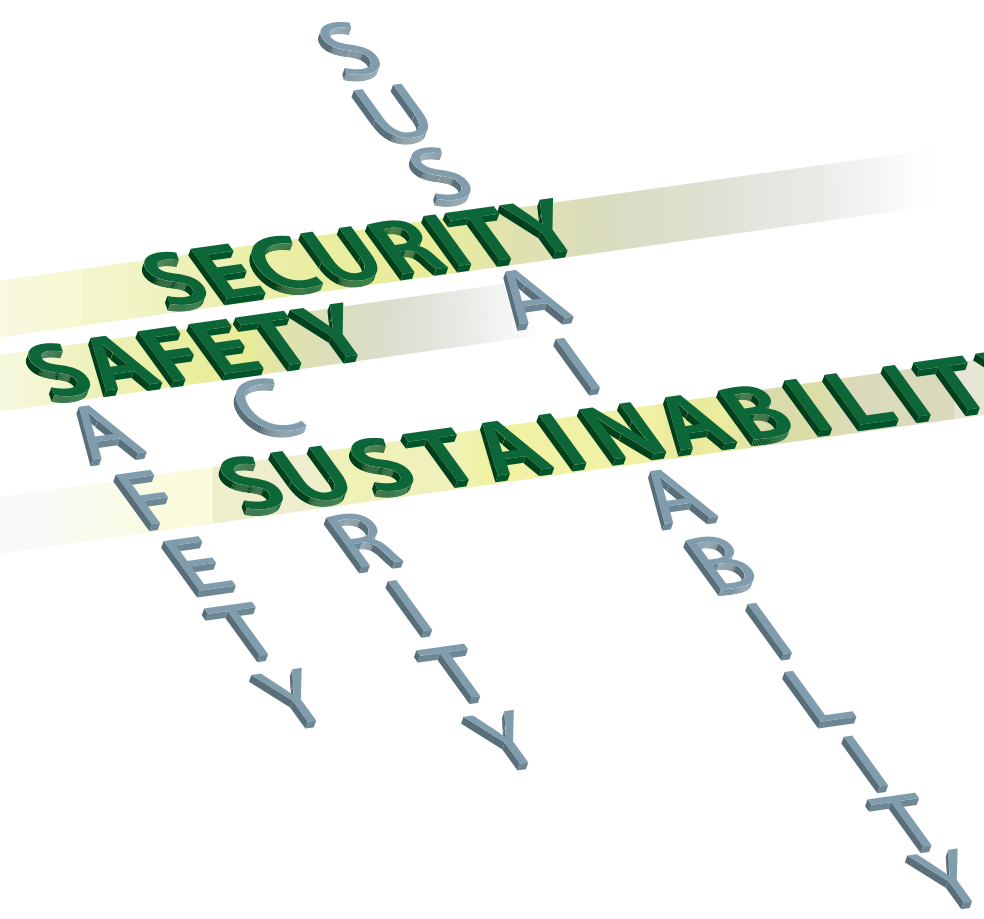

recordable case rate for injuries and illnesses in FY 2013 was 0.89 compared with 0.91 in FY 2012. "Days away, restricted, and transferred" (DART) cases were up compared with FY 2012: 10 cases in FY 2012 and 15 in FY 2013. The DART rate for FY 2013 was 0.35 compared with 0.23 for FY 2012. Although the DART rate was slightly higher, ORNL achieved more than 4 million hours worked without a DART case.

Improvement efforts in annual focus areas such as hazardous energy control implementation and pre-job briefings and implementation of worker safety and health requirements provided increased attention to these key areas. A strong trending and communication process contributed to improving safety awareness and addressing issues while they were still in nascent stages.

\section{Wellness Program}

ORNL's award winning Wellness Program is an example of the commitment to our most valuable resource, people. With an emphasis on prevention and employee involvement, the program offers free

- health assessments;

- consultations with ORNL's registered dietitian and exercise physiologist;

- health seminars and screenings;

- access to an on-site physical therapist;

- fitness assessments;

- fitness centers, available 24/7; and

- walking, jogging, and exercise programs.

To encourage employees to take an active part in improving their health, ORNL offers an incentive program through which they can earn a $\$ 30$ per month reduction in ORNL medical plan premiums. 
Following are some of the special events sponsored by the program in the past year during lunch periods.

- The annual ORNL Benefits and Wellness Fair (cosponsored with the ORNL Benefits group). One of the highlights of the health and fitness year, the fair introduces employees to various health and fitness vendors (typically about 100) from the surrounding community, who provide educational materials; conduct screenings, including mammograms, bone density, and blood sugar; and provide related information and services for ORNL employees. The last fair was held in 2012, and about 3,000 employees attended the fair, and 1,273 screenings were conducted.

- May HealthFest. In honor of National Employee Health and Fitness Day (the third Wednesday in May), the ORNL Wellness Program has turned the entire month of May into HealthFest, providing about 30 events and activities throughout the month, including a $10 \mathrm{~K}$, line and swing dance sessions, hikes, yoga, Pilates, fitness walks, bike rides, fitness challenges, lectures, belly dancing-virtually something for everyone.

- Santaclaustrophobia Challenge. An annual favorite in its 6th year in 2013, the program challenges participants to gain less than 2 pounds over the holiday season. In 2013 836 employees participated (a slight decrease compared to 2012), and 664 or roughly $80 \%$ met the challenge and kept their weight down to less than a 2-pound gain. After tallying all the gains and losses, the program netted 1,355 pounds of lost weight, compared to 2012's 1,416 pounds.

- Biggest Loser Team Challenge. A 12-week weight management program, the Biggest Loser has been conducted three times at ORNL, with about 47 teams, comprising a total of 236 employees, participating each time. A cumulative weight loss of 2,581 pounds was logged by program participants. A Biggest Loser maintenance group was run contiguously with 117 employees maintaining or losing weight during the 12 weeks.
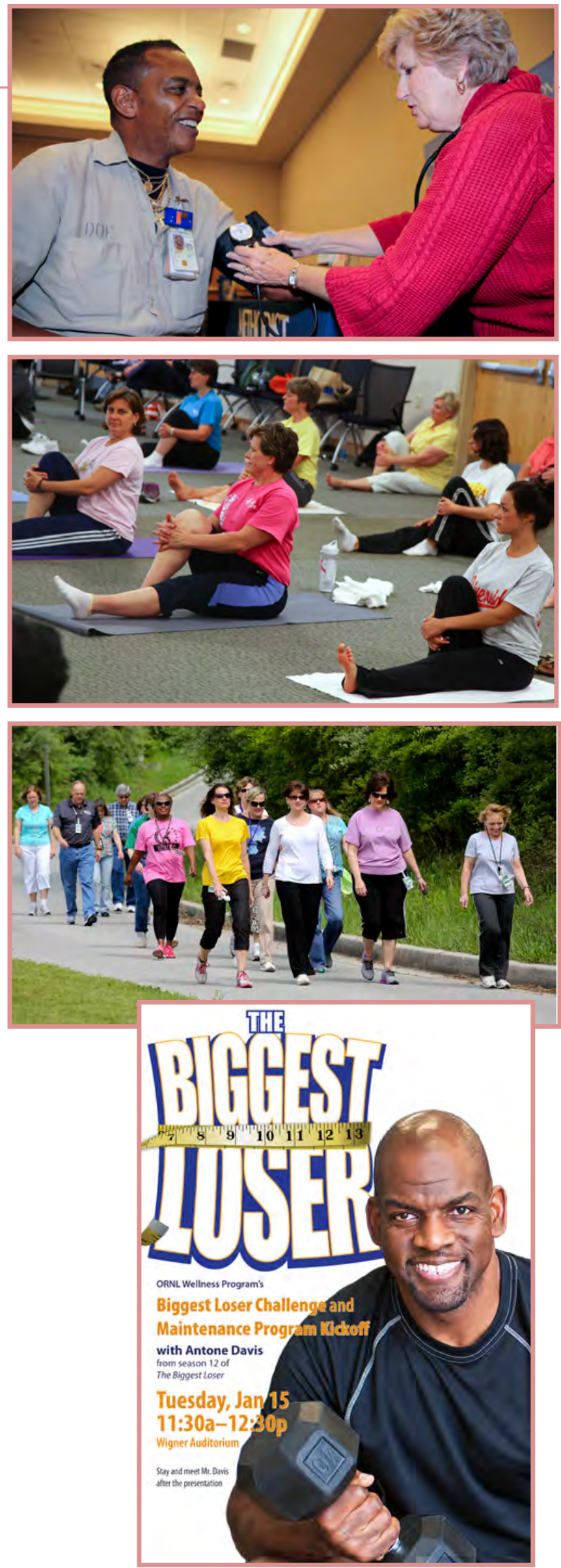


\section{Southeast Sustainability Summit}

ORNL partnered with the Tennessee Department of Environment and Conservation's Tennessee Energy Education Initiative (TEEI) and the City of Knoxville to host ORNL's 3rd Annual Southeast Sustainability Summit August 21-22, 2013, at the Holiday Inn World's Fair Park. The two previous summits were hosted on-site at ORNL, but the summit was moved to downtown Knoxville this year to allow for larger attendance-and the decision paid off, with close to 300 in attendance. The agenda covered topics as diverse as sustainable transportation, low-interest energy loans, changing behaviors in the workplace, and energy savings performance contracts. Keynote addresses were delivered by John L. Knott Jr. of CityCraft Ventures, Kateri Callahan of the Alliance to Save Energy, Lee Ann Head of the Shelton Group, and Mike Vandenbergh, Law Professor at Vanderbilt University. Vandenbergh, a leading scholar in environmental and energy law, spoke about his multidisciplinary research on behavior change in the workplace. ORNL speakers included Thom Mason, Martin Keller, Herb Debban, Melissa Lapsa, Scott Curran, John Shonder, Julia Kelley, and Roderick Jackson.

\section{ORNL Charter Member of New Sustainability Group}

During the summit, ORNL announced a new nonprofit sustainability organization, the Southeast Sustainability Group (SSG, http:// www.southeastsustainabilitygroup.org/). SSG comprises research, academic, and industry partners throughout the southeastern United
States with a shared vision for advancing sustainability in the region-defined primarily as the US Environmental Protection Agency's Region IV (Alabama, Florida, Georgia, Kentucky, Mississippi, North Carolina, South Carolina, Tennessee, and American Indian groups in the region). Initially SSG will focus on sustainable transportation, low-carbon power generation, and water and waste management. In addition to ORNL, other SSG members include Black Bear Solar Institute (Pigeon Forge, Tennessee), ClarkAtlanta University, Indian River State College (Florida), Nissan North America, the Tennessee Valley Authority, and the University of Tennessee-Knoxville.

\section{Community Sustainability Award}

SCI emphasizes sustainability at work, home, and in the community. In 2010, SCI initiated the Community Sustainability Award to honor ORNL individuals or teams making a significant contribution to community sustainability at the local, regional, national, or global level. Past recipients have been honored for such things as waterway cleanup and beautification projects and neighborhood renovation projects.

ORNL's fourth annual Community Sustainability Award was presented to Scott Curran, staff member in the Fuels, Engines, and Emissions Research group in the Energy and Transportation Science Division.

Because of Scott's participation in City of Oak Ridge, Knoxville, and ORNL Earth Day events over the last 5 years, including volunteering his personal time to bring alternative fuel vehicles to the events and spending time explaining to attendees the benefits of such vehicles, East Tennesseans are not only more knowledgeable of the technologies but also more aware of
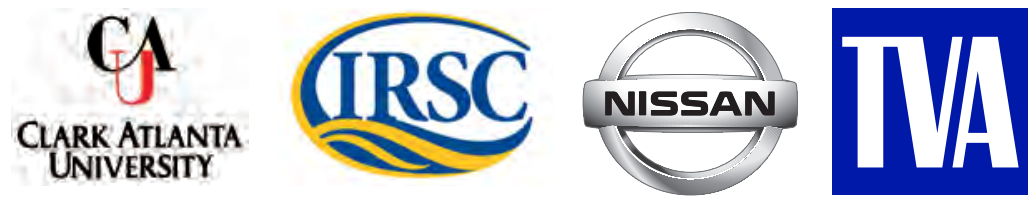
ORNL's leadership role in using alternative fuels and advanced technology vehicles. Scott also works with the local DOE Clean Cities Program year-round to make sure the public has access to current and accurate information on the benefits and challenges of alternative fuels and advanced vehicle technologies. Just as important, Scott supports the education of students of all ages, elementary school through college, on the benefits of alternative fuels and hybrid

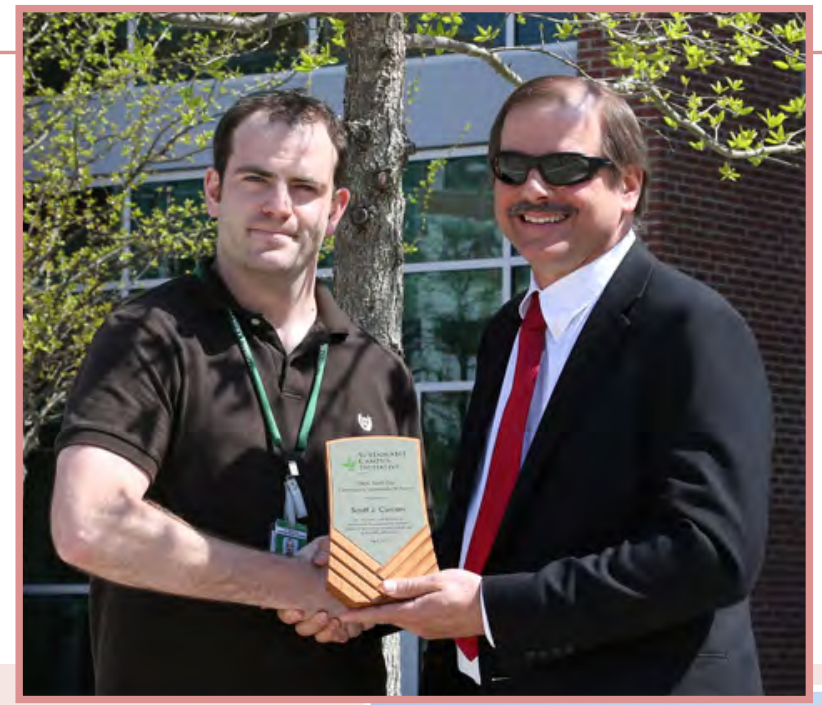

\section{Earth Day 2013}

Earth Day is another major event on the ORNL SCI calendar. ORNL's 2013 Earth Day theme, "You Can Make a Difference," was selected to emphasize that every one of us, by taking a few simple steps, can make a huge difference in the world we live in and leave to those who follow us. Scheduled events and activities at the $\mathrm{SCl}$-sponsored celebration, held over the lunch period, were selected to raise awareness of ways to globally and locally protect the environment, conserve our natural resources, and promote energy efficiency. In keeping with the spirit of Earth Day, the Tennessee Valley Authority provided ORNL with 1,500 kWh in Green Power Switch renewable energy credits to help offset the electrical consumption of the event. To put this into perspective, this is the equivalent of avoiding the $\mathrm{CO}_{2}$ emissions of more than $110 \mathrm{gal}$ of gas! Highlights of this year's event included-

- Science Showcases of green technologies developed through research at ORNL.

- Green Vendor Fair promoting environmentally friendly products from local vendors including everything from hybrid and battery-powered vehicles to energy efficient water filtration systems.

\section{- Alternative Fuel Car Show.}

- Biomass Steam Plant tours. The Biomass Steam Plant is one of the cornerstones of the ORNL program to reduce its greenhouse gas emissions.

- Nature Photography Exhibit showcasing the nature photography of 21 ORNL amateur photographers.

- How-To Information on healthy eating, gardening, recycling, native landscaping, and wellness.

The enthusiastic reception - thousands of UT-Battelle employees from across the area-was especially gratifying in light of the fact that recent polls have shown that many Americans are less concerned about the environment today than when Earth Day began more than 40 years ago. But Earth Dayas well as concern for sustainability-is alive and well at ORNL.
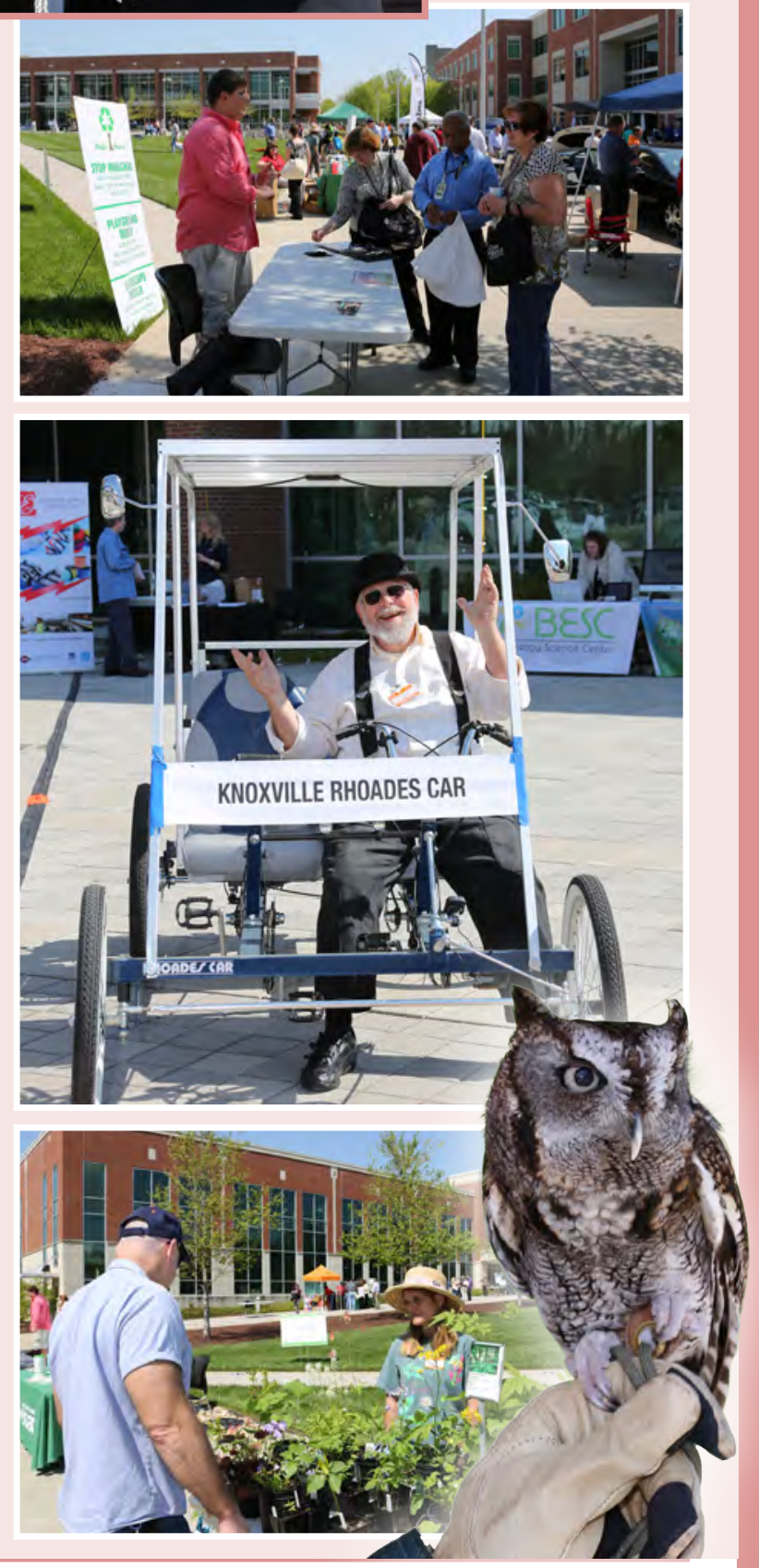


\section{Awards}

Achieving the goals we and others have set for us is gratifying in many ways, and it's great to be able to map our progress toward those sustainability goals. However, the respect and recognition of other organizations is important as well. As in past years, our sustainability efforts and achievements were recognized by a variety of different organizations and awards this year, of which we are justifiably proud and humbly grateful and from which we have been imbued with a renewed sense of dedication to the sustainability journey.

- 2012 DOE Bronze GreenBuy Award for Sustainable Acquisition

- 2012 DOE Outstanding Sustainability Projects for Water Resource Management

- 2012 three Tennessee Chamber of Commerce \& Industry Achievement/ Appreciation Certificates in Air Quality, Water Quality, and Environmental Excellence

- 2012 DOE Sustainability Performance Office Exceptional ServiceSustainability Champion-Greg Palko

- 2013 "Green Achievers" award by GoGreen East Tennessee for its participation in the GoGreen.com Business Recognition Program

- 2013 "Roane Beautification" award by the Roane County Industrial Development Board for its significant modernization and sustainable campus improvements rigorously made over the past decade

- 2013 GreenGov Presidential Award - Good Neighbor

- 2013 Federal Energy and Water Management Award

- 2013 Tennessee Chamber of Commerce and Industry - Air Quality Award

- 2013 DOE Sustainability Award - Green Steam ORNL Biomass Steam Plant

- 2013 DOE Sustainability Award - Change Agent - Susan Michaud

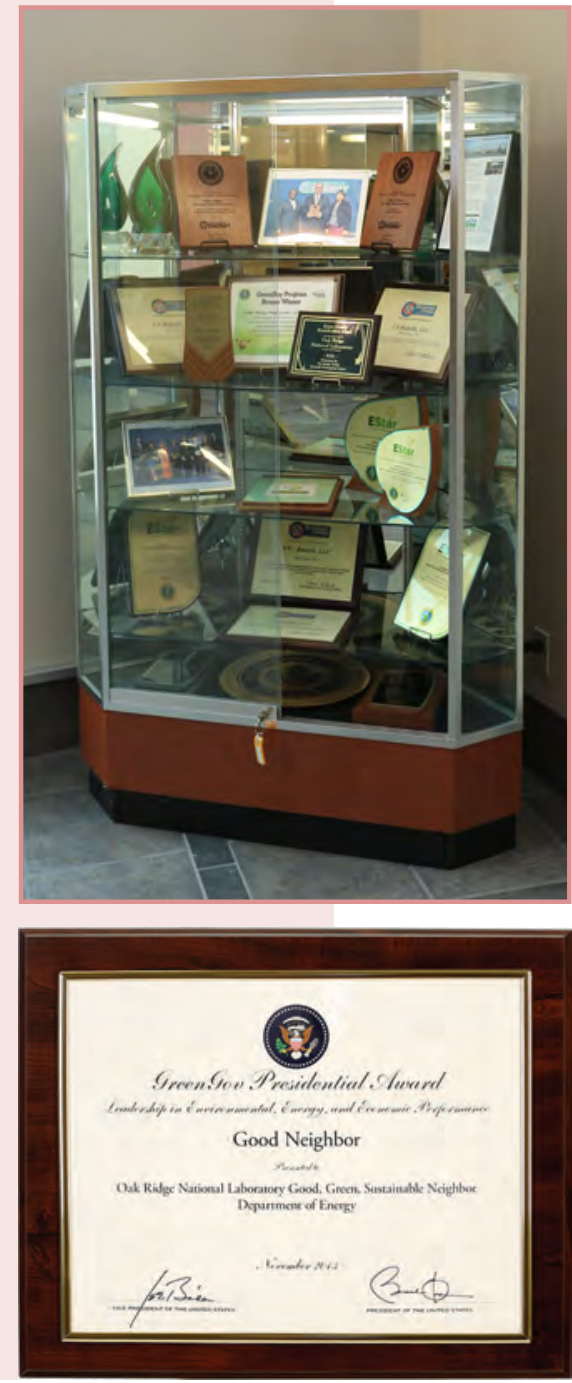

\section{Global Reporting Initiative and the Sustainable Campus Initiative}

As described throughout this report, ORNL has made substantial progress on the $25 \mathrm{SCI}$ roadmaps, which contributes significantly to progress in our Global Reporting Initiative (GRI) indicators. The summary table below provides information on many of these key GRI performance indicators. For more information on ORNL's GRI compliance, please refer to the expanded GRI table on the SCI website and type GRI Index in the search option to link to ORNL's GRI Index.

\section{Strategy and Analysis}

Statement from the most senior decision maker in the organization about the relevance of sustainability to the organization and its strategy.

Description of key impacts, risks, and opportunities.

\section{G4-1 Annual report, page 1, "Message from the Director"}

G4-2 http://www.ornl.gov/ornlhome/docs/fact.pdf

http://www.ornl.gov/about-ornl;

http://www.ornl.gov/ornl/about-ornl/environmental-policy 


\begin{tabular}{|c|c|c|}
\hline $\begin{array}{l}\text { General Standard GRI Disclosures }{ }^{\mathrm{a}} \\
\text { Organizational Profile }\end{array}$ & $\begin{array}{l}\mathbf{G 4}^{\mathrm{b}} \\
\text { Indicator }\end{array}$ & Page (in this report)/URL \\
\hline Name of the organization & G4-3 & Oak Ridge National Laboratory \\
\hline Primary brands, products, and services & G4-4 & $\begin{array}{l}\text { http://www.ornl.gov/ornlhome/docs/fact.pdf } \\
\text { http://www.ornl.gov/science-discovery }\end{array}$ \\
\hline Location of organization's headquarters & G4-5 & PO Box 2008, 1 Bethel Valley Road, Oak Ridge, Tennessee 37831-6266 \\
\hline Nature of ownership and legal form & G4-7 & http://www.ut-battelle.org/about.shtml \\
\hline Markets served & G4-8 & http://www.ornl.gov/ornlhome/docs/fact.pdf \\
\hline $\begin{array}{l}\text { How the precautionary approach or principle is } \\
\text { addressed by the organization }\end{array}$ & G4-14 & http://www.ornl.gov/ornlhome/environmental_policy.shtml \\
\hline \multicolumn{3}{|l|}{ Stakeholder Engagement } \\
\hline Stakeholder groups engaged by the organization & G4-24 & $\begin{array}{l}\text { http://www.ornl.gov/adm/partnerships/ } \\
\text { http://www.ornl.gov/ornlhome/community_outreach.shtml } \\
\text { http://web.ornl.gov/ornlhome/neighbors_stakeholders.shtml } \\
\text { Annual Report, page 22, Community Engagement }\end{array}$ \\
\hline $\begin{array}{l}\text { Basis for identification and selection of stake- } \\
\text { holders with whom to engage }\end{array}$ & G4-25 & http://www.ut-battelle.org/plan.shtml \\
\hline \multicolumn{3}{|l|}{ Report Profile } \\
\hline Reporting period & G4-28 & Fiscal Year \\
\hline Date of most recent report & G4-29 & $\begin{array}{l}\text { The Annual Sustainability Report is dated March 2012: http:// } \\
\text { sustainability-ornl.org/documents/Annual\%20Sustainability\%20 } \\
\text { Report_2012.pdf }\end{array}$ \\
\hline $\begin{array}{l}\text { Contact point for questions regarding the report } \\
\text { or its contents }\end{array}$ & G4-31 & $\begin{array}{l}\text { Teresa A. Nichols (nicholsta@ornl.gov), Sustainable Campus Initiative } \\
\text { Leadership Team Member }\end{array}$ \\
\hline \multicolumn{3}{|l|}{ Governance } \\
\hline Governance structure of the organization & G4-34 & $\begin{array}{l}\text { http://www.ut-battelle.org/about.shtml } \\
\text { http://www.ut-battelle.org/leadership.shtml }\end{array}$ \\
\hline $\begin{array}{l}\text { Executive-level position or positions with } \\
\text { responsibility for economic, environmental, and } \\
\text { social topics. }\end{array}$ & G4-36 & $\begin{array}{l}\text { http://www.ut-battelle.org/leadership.shtml } \\
\text { http://www.ornl.gov/ornl/about-ornl/organization }\end{array}$ \\
\hline \multicolumn{3}{|l|}{ Ethics and Integrity } \\
\hline $\begin{array}{l}\text { Organization's values, principles, standards, and } \\
\text { norms of behavior such as codes of conduct and } \\
\text { codes of ethics }\end{array}$ & G4-56 & http://www.ornl.gov/ornl/about-ornl/research-integrity \\
\hline
\end{tabular}

aGRI defines "General Standard Disclosures" as things that "offer a description of the organization and the reporting process."

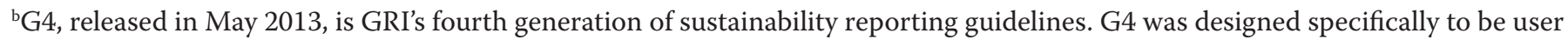
friendly and applicable to all types and sizes of organizations around the world. It is up to individual organizations to decide when and how they will transition from earlier versions to the G4 guidelines; however, GRI has said that reports published after December 31, 2015, will have to be prepared in accordance with the G4 guidelines to be GRI compliant. Because of this, ORNL decided to start transitioning with this year's annual sustainability report. 

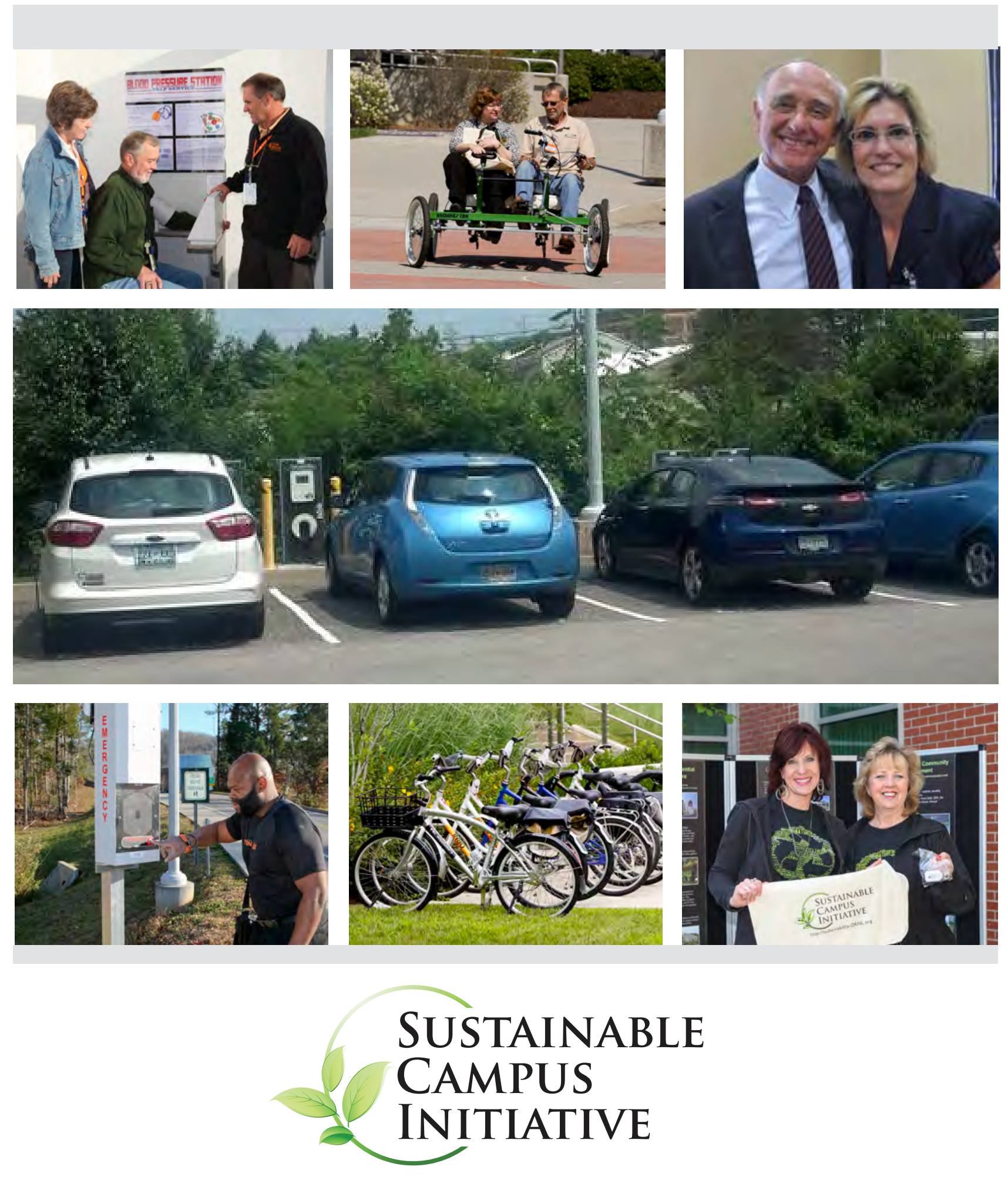

\section{CONTACTS:}

Melissa Lapsa

(865) 576-8620

lapsamv@ornl.gov
Teresa Nichols

(865) 576-0541

nicholsta@ornl.gov 